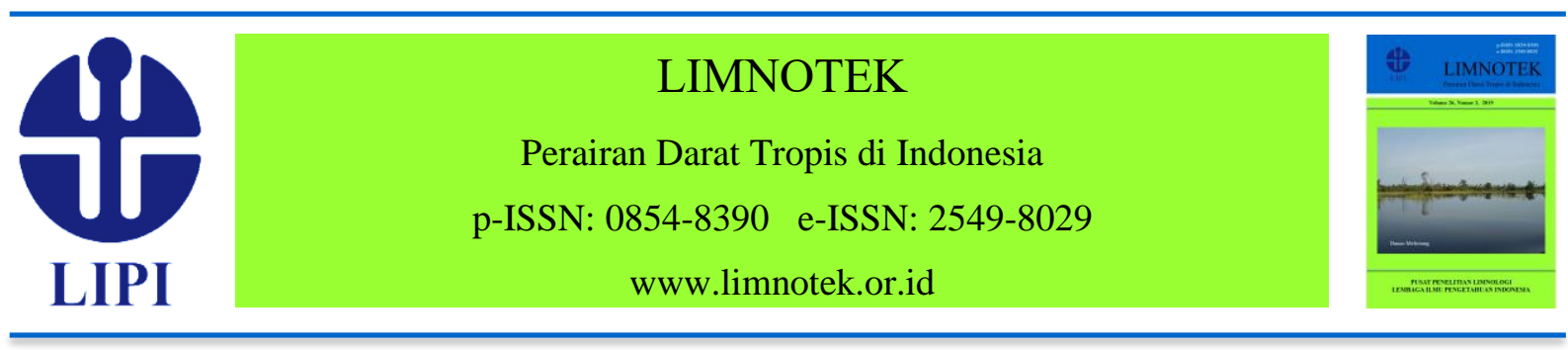

\title{
Kerapatan Populasi Makrofita Berpengaruh terhadap Kelimpahan dan Keanekaragaman Mikroalga Epifiton di Danau Tempe
}

\author{
Nofdianto dan Livia Rossila Tanjung
}

Pusat Penelitian Limnologi, Lembaga Ilmu Pengetahuan Indonesia

Email: nofdianto@limnologi.lipi.go.id

Diajukan 17 Mei 2019. Ditelaah 23 Oktober 2019. Disetujui 20 Desember 2019.

\begin{abstract}
Abstrak
Danau paparan banjir seperti Danau Tempe memiliki potensi perikanan air tawar cukup besar karena didukung oleh keunikan dalam hal produktivitasnya yang sangat tinggi pada musim hujan. Selain berfungsi sebagai komponen utama dalam produktivitas danau dan sebagai feeding ground bagi berbagai spesies ikan, tumbuhan air atau makrofita yang tumbuh subur di pinggir danau juga merupakan substrat bagi mikroalga epifiton yang berperan penting dalam produktivitas sekunder danau. Penelitian ini bertujuan untuk memastikan bahwa pengendalian kerapatan tumbuh makrofita sebagai substrat mikroalga epifiton penting dilakukan untuk mendukung keberlanjutan produktivitas perikanan berbasis ekosistem. Penelitian ini dilakukan di Danau Tempe pada bulan Maret, Mei, dan Juli 2017 terhadap kerapatan makrofita yang berbeda berdasarkan penerimaan cahaya. Sampel berupa batang makrofita dengan panjang $10 \mathrm{~cm}$ yang terendam dalam air diambil secara komposit sebanyak 5 batang, lalu disikat untuk mendapatkan mikroalga epifiton. Identifikasi epifiton dilakukan di Laboratorium Pusat Penelitian Limnologi LIPI. Hasilnya menunjukkan bahwa kerapatan tumbuh makrofita berpengaruh negatif terhadap kelimpahan dan keanekaragaman mikroalga epifiton di Danau Tempe. Kerapatan makrofita memengaruhi intensitas cahaya yang diterima epifiton, sehingga makrofita dengan kerapatan rendah memiliki kelimpahan epifiton lebih tinggi dibandingkan makrofita yang tumbuh rapat. Dengan demikian, pengaturan kerapatan makrofita dapat menjadi salah satu strategi dalam pengelolaan sumber daya perikanan dengan menjaga keberlanjutan populasi epifiton sebagai produsen primer yang penting untuk mendukung produktivitas di perairan danau dangkal seperti Danau Tempe.
\end{abstract}

Kata kunci: makrofita, mikroalga epifiton, kerapatan tumbuh, produktivitas perikanan, Danau Tempe

\begin{abstract}
The density of macrophyte population influences the abundance and diversity of epiphytic microalgae in tropical floodplain Lake Tempe. Tropical floodplain such as Lake Tempe has a considerable potential for freshwater fisheries due to its very high productivity during the rainy season. In addition to their function as the main component in lake productivity and as a feeding ground for various fish species, aquatic plants or macrophytes that thrive in the littoral zone of
\end{abstract}


floodplain lake constitute a substrate for epiphytic microalgae that support secondary productivity of the lake. This study aims to prove that controlling of macrophytes density as epiphytic microalgae substrates is important to support the sustainable productivity of ecosystem-based fisheries. This study was carried out in Lake Tempe in March, May, and July 2017 at different macrophyte densities referring to the different light penetration. Samples, in the form of submerged plant stems, with a length of $10 \mathrm{~cm}$ were taken in a composite of five stems, and then brushed to collect the epiphyte microalgae. Epiphyte identification was carried out at the LIPI Limnology Research Center Laboratory. The results showed that macrophytes density negatively affected the abundance of epiphyte microalgae in Lake Tempe. Macrophyte density influences the intensity of light received by epiphyton, so macrophytes with low density have higher epiphyton abundance than macrophytes that grow tightly. Hence, regulation of macrophyte density would be a useful strategy in the fisheries resource management by maintaining the sustainability of epiphyte populations as important primary producers to support productivity in shallow lake waters such as Lake Tempe.

Keywords: macrophytes, epiphytic microalgae, density, fishery productivity, Lake Tempe

\section{Pendahuluan}

Danau Tempe merupakan danau paparan banjir yang terletak di Kecamatan Tempe, Kabupaten Wajo, sekitar $7 \mathrm{~km}$ dari Kota Sengkang. Pada musim hujan, luas danau mencapai lebih dari 30.000 ha dengan kedalaman maksimum 5,5 m saat banjir, namun pada musim kemarau luasnya hanya mencapai 1.000 ha dengan kedalaman maksimum $1 \mathrm{~m}$ (Samuel et al., 2010). Sejak sekitar 40 tahun yang lalu, Danau Tempe sudah menghadapi masalah yang berkaitan dengan produktivitas perairannya karena aktivitas penangkapan ikan yang terlalu tinggi. Akibatnya, produksi perikanan Danau Tempe yang pernah mencapai 16.500 ton per tahun pada tahun 1955 menurun hingga 4.500 ton per tahun pada tahun 19741977 (Samuel et al., 2010). Selain itu, masalah yang berkaitan dengan isu lingkungan seperti pencemaran, eutrofikasi yang menyebabkan ledakan populasi tumbuhan air dan pendangkalan danau masih menjadi masalah yang belum teratasi di Danau Tempe (Aisyah \& Nomosatryo, 2016).

Tumbuhan air yang disebut juga hidrofita atau makrofita merupakan vegetasi akuatik yang tumbuh di sekitar perairan. Tumbuhan air dapat ditemui dalam posisi mencuat dari permukaan air (emergent), melayang di dalam air (submergent), atau mengapung di permukaan air (floating). Selain sebagai substrat bagi epifiton dan mikrofauna, makrofita yang hidup terendam dalam air juga memainkan peran penting dalam menentukan pola keanekaragaman hayati di perairan tersebut (Pelicice et al., 2008).
Makrofita di danau paparan banjir memiliki peran ekologis penting di samping sebagai produsen primer. Makrofita yang berada di bawah permukaan air menyediakan habitat dalam bentuk tempat perlindungan bagi hewan air yang menjadi mangsa hewan predator. Makrofita juga berfungsi sebagai substrat bagi mikroalga epifiton yang pertumbuhannya mungkin terhambat karena ternaung, air yang dalam, atau kekeruhan (Pettit et al., 2011). Selain itu, makrofita berperan penting dalam mendukung pembentukan rantai makanan dan proses-proses kimia, fisika, dan biologis di ekosistem perairan dengan menyediakan struktur fisik, meningkatkan kompleksitas habitat, heterogenitas dan fisikokimia, serta memengaruhi berbagai organisme lain seperti invertebrata, ikan, dan burung air (Thomaz \& Cunha, 2010).

Potensi makrofita di Danau Tempe sangat besar, sehingga masyarakat di sekitar danau telah lama memanfaatkan vegetasi ini sebagai alat penangkapan ikan yang dikenal dengan Bungka Toddo, yakni mengumpulkan makrofita di tengah danau untuk menarik perhatian ikan, setelah ikan berkumpul di sekitar makrofita tersebut, pemanenan ikan dilakukan secara massal (Nofdianto, 2013). Berbagai spesies makrofita banyak ditemui di Danau Tempe, seperti mansiang (Scirpus grossus), ganggang (Hydrilla verticillata), cowehan (Ottelia alismoides), teratai (Nymphaea lotus), rumput bebek (Echinochloa colonum), mengkrengan (Polygonum barbatum), eceng gondok (Eichhornia crassipes), rumput para (Cyperus platystylis), 
dan genjer (Limnocharis flava) (Nasir \& Nur, 2017).

Mikroalga epifiton merupakan bagian dari perifiton yang hidup menempel di bagian makrofita yang terendam dan berperan sebagai produsen primer (Dere et al., 2002). Mikroalga epifiton merupakan sumber nutrisi utama hewan invertebrata seperti zooplankton, makrozoobenthos, dan meiofauna dan penting untuk menilai status trofik danau (Jaschinski et al., 2011; Stenger-Kovács et al., 2007). Kelimpahan dan struktur komunitas epifiton dipengaruhi oleh morfologi, fisiologi, dan kerapatan tumbuh makrofita sebagai substratnya (Pettit et al., 2016; Woods, 2013).

Makrofita dan epifiton sama-sama membutuhkan energi cahaya yang berperan penting dalam proses fotosintesis. Peningkatan intensitas cahaya akan meningkatkan laju fotosintesis selama faktor-faktor lain seperti suhu, $\mathrm{CO}_{2}$, dan air tersedia dalam jumlah yang memadai (Benckiser, 2019). Makrofita yang tumbuh di perairan danau dengan kerapatan yang berbeda-beda akan merefleksikan tingkat intensitas cahaya yang berbeda-beda pula yang akan diterima oleh epifiton yang menempel pada permukaan makrofita yang terendam.

Populasi makrofita yang tumbuh rapat akan menurunkan intensitas cahaya yang diterima oleh epifiton. Sebaliknya, pada populasi makrofita yang tumbuh jarang, intensitas cahaya yang diterima oleh epifiton akan meningkat, sehingga fotosintesis bisa berlangsung lebih baik. Berkaitan dengan hal tersebut, dalam rangka meningkatkan produktivitas perikanan di Danau Tempe, pengelolaan jenis dan kerapatan makrofita sebagai substrat bagi epifiton menjadi hal penting di kawasan konservasi karena hal ini berhubungan langsung dengan suksesi dan kelimpahan produktivitas yang bersumber dari mikroalga epifiton. Tulisan ini memaparkan hasil studi tentang kelimpahan dan keanekaragaman mikroalga epifiton yang bergantung pada intensitas cahaya yang diterima oleh epifiton tersebut sebagai dampak perbedaan kerapatan tumbuh makrofita tempat menempelnya. Hasil penelitian ini diharapkan menjadi salah satu acuan dalam pengelolaan zona riparian di Danau Tempe untuk meningkatkan produktivitasnya sebagai penghasil ikan air tawar di Sulawesi Selatan.

\section{Bahan dan Metode}

Penelitian dilakukan dengan metode survei pada bulan Maret, Mei, dan Juli 2017. Pengambilan sampel makrofita sebagai substrat mikroalga epifiton dilakukan di lima zona yang terdiri dari 11 stasiun, yaitu Stasiun 1.1-1.5 dan Stasiun 2.1-2.2 mewakili daerah palawang, yaitu daerah yang digunakan sebagai lahan ladang atau persawahan pada musim kering, daerah rumah apung, dan kawasan penangkapan ikan, Stasiun 3.1 mewakili daerah yang sangat bergelombang dan berangin serta tersambung dengan Danau Sidendreng, Stasiun 4.1-4.2 mewakili daerah muara (Sungai Bila), juga dipengaruhi oleh gelombang dan angin, dan Stasiun 5.2 mewakili daerah timur laut yang dekat dengan permukiman. Kesebelas stasiun pengambilan sampel tersebar di semua zona (Gambar 1) dengan jumlah stasiun di masingmasing zona disesuaikan dengan keberadaan dan kerapatan makrofita serta luas zona tersebut, yaitu Stasiun 1.1, 1.2, 1.3, 1.4, 1.5, 2.1, 2.2, 3.1, 4.1, 4.2, 5.2 yang bervegetasi rapat (R) dan jarang (J).

Kerapatan makrofita dibagi menjadi dua kelompok, yaitu kelompok makrofita dengan kerapatan rendah (vegetasi jarang, VJ), ditetapkan dengan nilai intensitas cahaya tinggi, yaitu 10.752 lux atau lebih tepat di bawah tajuk dan kelompok makrofita dengan kerapatan tinggi (vegetasi rapat, VR), ditetapkan dengan intensitas cahaya rendah bernilai kurang dari 10.752 lux. Pembagian ini berdasarkan National Optical Astronomy Observatory (NOAO) yang menyatakan bahwa intensitas cahaya pada siang hari (full daylight) yang bukan merupakan cahaya matahari langsung (sunlight) bernilai 10.752 lux (NOAO, n.d.). Sampling makrofita sebagai substrat epifiton dilakukan terhadap beberapa jenis makrofita yang ditemukan di setiap stasiun dan mewakili kedua kelompok kerapatan atau nilai intensitas cahaya. 

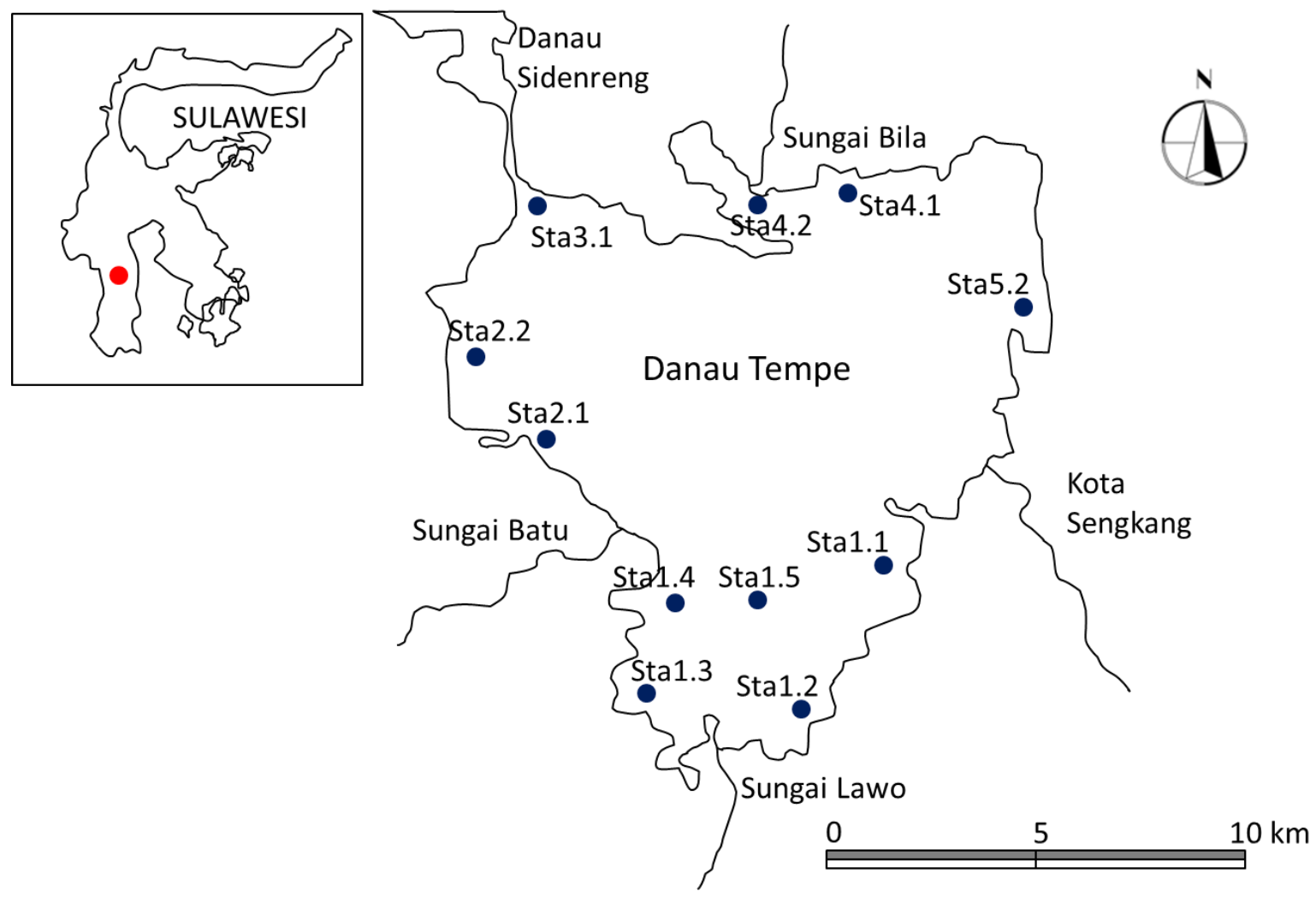

Gambar 1. Stasiun pengambilan sampel di Danau Tempe

Titik sampling ditentukan 10-20 m dari tepi danau. Di setiap titik sampling, diambil sampel berupa bagian batang tumbuhan yang terendam sekitar 10-15 $\mathrm{cm}$ di bawah permukaan air dengan cara komposit sebanyak 5 batang dengan panjang masing-masing $10 \mathrm{~cm}$. Penelitian ini difokuskan pada kedua kategori intensitas cahaya yang diterima epifiton, sehingga pencacahan jumlah batang makrofita per satuan luas perairan tidak dilakukan.

Sampel batang lalu dimasukkan ke wadah plastik yang sudah berisi aquades, diberi label dan disimpan dalam coolbox sebelum dibawa ke laboratorium. Mikroalga epifiton diperoleh dengan cara menyikat sampel batang makrofita dengan sikat plastik sambil ditampung dan disaring dengan net plankton no. 25 , kemudian larutan lugol 4\% ditambahkan sebagai pengawet dengan konsentrasi akhir $1 \%$ $(1: 100)$ dan berwarna kuning kecoklatan (APHA, 2015). Selanjutnya, luas permukaan substrat batang makrofita diukur dengan menggunakan jangka sorong digital.

Pemeriksaan mikroalga epifiton dilakukan di Laboratorium Pusat Penelitian Limnologi LIPI, Cibinong. Pemeriksaan secara kualitatif dilakukan dengan mengidentifikasi taxa alga epifiton menggunakan buku kunci identifikasi (Mizuno, 1979; Prescott, 1970). Analisis kuantitatif dilakukan dengan penghitungan secara langsung menggunakan alat Sedgewick rafter $1 \mathrm{~mL}$ dengan hasil dikonversi ke luas substrat epifiton (APHA, 2015).

Nilai-nilai struktur komunitas seperti indeks keanekaragaman jenis Shannon-Wiener $(\mathrm{H})$, indeks kemerataan jenis Pielou (E), dan indeks dominansi Simpson (D) dihitung berdasarkan Odum (1971). Indeks keanekaragaman jenis Shannon-Wiener (H) menentukan tingkat keanekaragaman spesies dalam suatu komunitas. Nilai $\mathrm{H}$ umumnya berkisar antara 0 dan 5 dengan tingkat keanekaragaman tinggi jika $\mathrm{H}>3$, sedang jika $2 \leq \mathrm{H} \leq 3$, dan rendah jika $0<\mathrm{H}<2$.

$$
\mathrm{H}=-\sum_{\mathrm{i}=1}^{\mathrm{s}} \mathrm{pi} \ln (\mathrm{pi})
$$

dengan $\mathrm{pi}=$ proporsi individu setiap spesies, yaitu jumlah individu setiap spesies per jumlah total individu semua spesies. 
Indeks kemerataan jenis Pielou (E) menggambarkan kestabilan suatu komunitas. Nilai indeks kemerataan jenis berkisar dari 0 hingga 1. Nilai $\mathrm{E}<0,4$ menunjukkan kemerataan spesies rendah, $0,4 \leq \mathrm{E} \leq 0,6$ menunjukkan kemerataan spesies sedang, dan $\mathrm{E}$ $>0,6$ menunjukkan kemerataan spesies tinggi. Nilai $E=0$ berarti jumlah individu yang dimiliki masing-masing spesies sangat jauh berbeda. Nilai $E=1$ berarti spesies relatif merata atau jumlah individu masing-masing spesies relatif sama.

$$
E=\frac{H}{\ln S}
$$

dengan $\mathrm{H}=$ indeks keanekaragaman ShannonWiener dan $\mathrm{S}=$ jumlah spesies dalam sampel.

Dominansi (D) diukur menggunakan indeks Simpson dengan rumus:

$$
\mathrm{D}=\sum_{\mathrm{i}=1}^{\mathrm{s}}\left(\frac{\mathrm{N}_{\mathrm{i}}}{\mathrm{N}_{\mathrm{S}}}\right)^{2}
$$

dengan $\mathrm{N}_{\mathrm{i}}=$ jumlah individu dalam setiap spesies dan $\mathrm{N}_{\mathrm{S}}=$ jumlah total individu dalam sampel.

Nilai $\mathrm{D}$ berkisar dari 0 hingga 1 . Nilai $\mathrm{D} \leq 0,5$ berarti tidak ada spesies yang dominan atau komunitas berada dalam kondisi stabil, sedangkan bila $0,5<\mathrm{D}<1,0$ berarti ada spesies yang dominan atau komunitas berada dalam kondisi labil karena terjadi tekanan ekologis.

Dominansi (d) juga diukur menggunakan indeks Berger-Parker (Caruso et al., 2007) dengan rumus:

$$
\mathrm{d}=\frac{\mathrm{N}_{\mathrm{S}}}{\mathrm{N}_{\mathrm{T}}}
$$

dengan $\mathrm{N}_{\mathrm{S}}=$ jumlah individu dalam spesies yang paling berlimpah dan $\mathrm{N}_{\mathrm{T}}=$ jumlah total individu dalam sampel.

Peningkatan nilai indeks Berger-Parker menyertai peningkatan dominansi dan penurunan kemerataan. Dalam sampel dengan jumlah spesies yang besar $(>100)$, d tidak tergantung pada jumlah spesies, tetapi bila jumlah spesies dalam sampel lebih kecil, nilai d akan cenderung menurun dengan peningkatan jumlah spesies. Dominansi tinggi akan menunjukkan keanekaragaman yang rendah.
Kekayaan jenis adalah jumlah berbagai spesies dalam suatu komunitas ekologi. Dalam penelitian ini, kekayaan jenis diperoleh dengan menghitung jumlah spesies tanpa mempertimbangkan kelimpahan spesies atau distribusi kelimpahan relatifnya.

Parameter kualitas air seperti suhu, $\mathrm{pH}$, oksigen terlarut (DO), konduktivitas, dan turbiditas diukur langsung pada kedalaman 10 $\mathrm{cm}$ di bawah permukaan air menggunakan Water Quality Checker (WQC) Horiba U-10 dan DOmeter YSI. Selain itu, sampel air danau diambil sebanyak masing-masing $250 \mathrm{~mL}$ untuk menganalisis kandungan fosfat, TN, dan TP menggunakan metode standar (APHA, 2015).

Analisis varian (Anova) faktor tunggal untuk menentukan perbedaan kelimpahan epifiton antara vegetasi jarang dan vegetasi rapat dilakukan menggunakan perangkat lunak Microsoft Excel 2010. Data komposisi dan kelimpahan epifiton serta fisika kimia air danau dianalisis menggunakan Principal Component Analysis (PCA) dengan perangkat lunak MVSP versi 3.1 untuk melihat sebaran variabel utama dan ordinasi tidak langsung antara jenis epifiton dominan dan parameter fisika kimia yang memiliki pengaruh lebih kuat di setiap stasiun penelitian.

\section{Hasil}

Secara umum, makrofita yang banyak ditemukan pada saat pengambilan sampel di sepanjang tepian danau yaitu kangkung (Ipomoea aquatica), buang-buang (Ludwigia adscendens), dan teki-teki (Cyperus sp.). Namun, sampel makrofita yang diambil dari stasiun bervegetasi rapat yaitu mengkrengan (Polygonum barbatum) dan eceng gondok (Eichhornia crassipes), sedangkan dari stasiun bervegetasi jarang terdiri dari kangkung (Ipomoea aquatica) dan buang-buang (Ludwigia adscendens).

Intensitas cahaya (Tabel 1) di lokasi bervegetasi jarang selama penelitian berkisar dari 12.200 lux (Stasiun 1.4; Mei) hingga 139.500 lux (Stasiun 5.2; Juli), sedangkan di lokasi bervegetasi rapat berkisar dari 700 lux (Stasiun 1.4; Mei) hingga 6.900 lux (Stasiun 5.2; Juli). Hasil ini sesuai dengan pembagian kerapatan makrofita atau intensitas cahaya menjadi dua kelompok, yaitu kelompok vege- 
Tabel 1. Hasil pengukuran intensitas cahaya (lux) di setiap stasiun pada kondisi vegetasi jarang (VJ) dan vegetasi rapat (VR)

\begin{tabular}{rrrrr}
\hline & Stasiun & \multicolumn{1}{c}{ Maret } & \multicolumn{1}{c}{ Mei } & \multicolumn{1}{c}{ Juli } \\
\hline & 1.1 & 36.900 & - & 82.600 \\
& 1.2 & 68.500 & 108.600 & 64.300 \\
& 1.3 & 129.100 & 24.400 & 59.200 \\
& 1.4 & 39.800 & 12.200 & - \\
VJ & 1.5 & 63.100 & 21.000 & 60.300 \\
& 2.1 & 118.900 & 39.400 & 73.400 \\
& 2.2 & 106.800 & 130.400 & 111.800 \\
& 3.1 & 34.900 & 112.100 & 75.200 \\
& 4.1 & 96.900 & 128.900 & 33.200 \\
& 4.2 & 122.400 & 94.800 & 29.600 \\
& 5.2 & 32.900 & 52.800 & 139.500 \\
\hline \multirow{4}{*}{ VR } & 1.1 & 1.800 & & 4.100 \\
& 1.2 & 3.400 & 5.400 & 3.200 \\
& 1.3 & 6.500 & 1.200 & 2.900 \\
& 1.4 & 1.900 & 700 & - \\
& 1.5 & 3.200 & 1.000 & 3.000 \\
& 2.1 & 5.900 & 1.900 & 3.600 \\
& 2.2 & 5.300 & 6.500 & 5.600 \\
3.1 & 1.700 & 5.600 & 3.700 \\
& 4.1 & 4.800 & 6.400 & 1.700 \\
4.2 & 6.100 & 4.700 & 1.500 \\
& 5.2 & 1.600 & 2.600 & 6.900 \\
\hline
\end{tabular}

tasi jarang dengan intensitas cahaya tinggi $(\geq 10.752$ lux $)$ dan kelompok vegetasi rapat dengan intensitas cahaya rendah ( $<10.752$ lux $)$.

Untuk kedua kondisi vegetasi jarang dan rapat, nilai minimum intensitas cahaya selalu diperoleh di Stasiun 1.4 pada bulan Mei, sedangkan nilai maksimumnya selalu ditemui di Stasiun 5.2 pada bulan Juli.

Penelitian ini berhasil mengidentifikasi tiga kelas mikroalga epifiton, yaitu Cyanophyceae atau mikroalga biru-hijau, Chlorophyceae atau mikroalga hijau, dan Chrysophyceae atau kelompok alga Diatom (Tabel 2) dengan kepadatan masing-masing kelas ditunjukkan dalam Gambar 2. Pada bulan Maret dan Mei, spesies dominan yaitu Rivularia sp. (Cyanophyceae) dan Stigeoclonium sp. (Chlorophyceae), sedangkan pada bulan Juli spesies dominan selain Rivularia sp. (Cyanophyceae) dan Stigeoclonium sp. (Chlorophyceae) adalah Spirogyra sp., dan Chaetophora sp. yang mendominasi beberapa stasiun. Kelimpahan tertinggi spesies dari masing-masing kelas ditemukan pada bulan Juli, yaitu Rivularia sp. dan Stigeoclonium sp. di Stasiun 2.1J, serta Navicula sp. di Stasiun 5.2R.

Kepadatan epifiton untuk vegetasi rapat berkisar 1.556-9.244 individu/ $\mathrm{dm}^{2}$, sedangkan untuk vegetasi jarang berkisar 17.956-34.578 individu/ $\mathrm{dm}^{2}$ (Gambar 2). Kelimpahan epifiton baik di vegetasi rapat maupun di vegetasi jarang menunjukkan perbedaaan yang signifikan $(P<$ $0,05)$ antara bulan Maret dan Juli serta antara bulan Mei dan Juli. 
Tabel 2. Komposisi dan kepadatan epifiton pada kedua tipe substrat J dan R dari setiap stasiun pada bulan Maret, Mei, dan Juli 2017

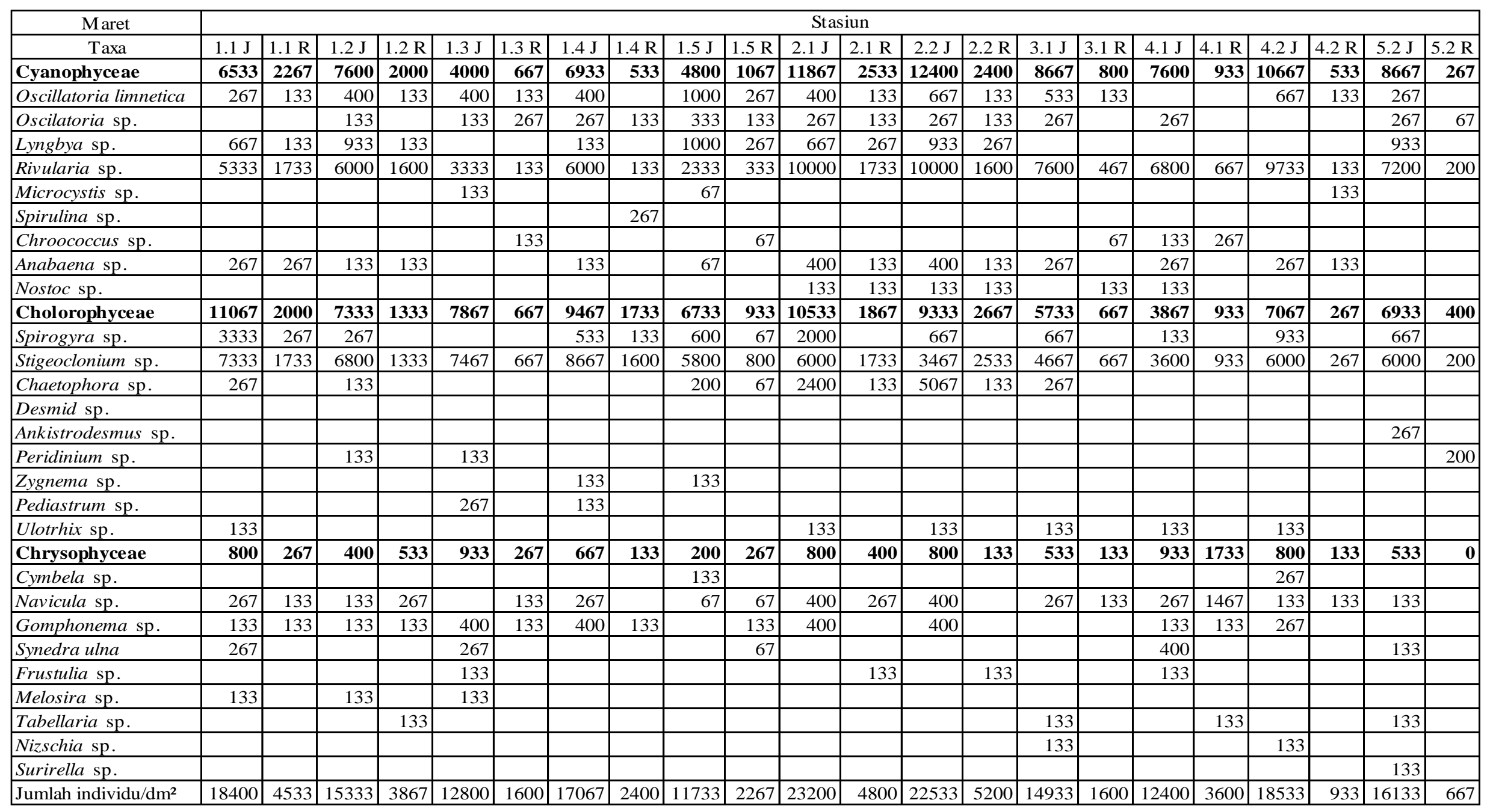




\begin{tabular}{|c|c|c|c|c|c|c|c|c|c|c|c|c|c|c|c|c|c|c|c|c|c|c|}
\hline Mei & \multicolumn{22}{|c|}{ Stasiun } \\
\hline Taxa & $1.1 \mathrm{~J}$ & $1.1 \mathrm{R}$ & $1.2 \mathrm{~J}$ & $1.2 \mathrm{R}$ & $1.3 \mathrm{~J}$ & $1.3 \mathrm{R}$ & $1.4 \mathrm{~J}$ & $1.4 \mathrm{R}$ & $1.5 \mathrm{~J}$ & $1.5 \mathrm{R}$ & $2.1 \mathrm{~J}$ & $2.1 \mathrm{R}$ & $2.2 \mathrm{~J}$ & \begin{tabular}{|l|l|}
$2.2 \mathrm{R}$ \\
\end{tabular} & $3.1 \mathrm{~J}$ & $\begin{array}{ll}3.1 \mathrm{R} \\
\end{array}$ & $4.1 \mathrm{~J}$ & $4.1 \mathrm{R}$ & $4.2 \mathrm{~J}$ & $4.2 \mathrm{R}$ & $5.2 \mathrm{~J}$ & $5.2 \mathrm{R}$ \\
\hline Cyanophyceae & 9600 & 800 & 2933 & 800 & 8000 & 400 & 400 & 533 & 10400 & 800 & 14800 & 5733 & 10800 & 2533 & 8667 & 333 & 17333 & 5333 & 6000 & 667 & 8933 & 1067 \\
\hline Oscillatoria limnetica & 533 & & 667 & & 400 & 133 & & & 3800 & 267 & 1600 & 133 & 400 & 133 & 533 & 133 & & & 1333 & 133 & & \\
\hline Oscilatoria sp. & & 133 & 800 & 133 & & 267 & 133 & 133 & 933 & & & & 267 & 133 & 267 & & 1333 & 267 & & & 267 & 67 \\
\hline Lyngbya $\mathrm{sp}$. & 4400 & & & 133 & 3067 & & 133 & & 3667 & & 2267 & & 933 & & & & 267 & 133 & & & 133 & \\
\hline Rivularia sp. & 4667 & 667 & 1333 & 400 & 4533 & & & 133 & 1667 & 467 & 10933 & 5600 & 8667 & 2000 & 7600 & & 14667 & 4667 & 4000 & 267 & 8533 & 1000 \\
\hline Microcystis sp. & & & 133 & & & & & & 200 & & & & & & & & & & & 133 & & \\
\hline 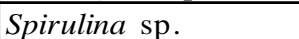 & & & & & & & & 267 & 133 & & & & & & & & & & & & & \\
\hline Chroococcus sp. & & & & & & & & & & 67 & & & & & & 67 & 133 & 267 & & & & \\
\hline Anabaena sp. & & & & 133 & & & 133 & & & & & & 400 & 133 & 267 & & 800 & & 667 & 133 & & \\
\hline Nostoc sp. & & & & & & & & & & & & & 133 & 133 & & 133 & 133 & & & & & \\
\hline Cholorophyceae & 16800 & 533 & 7867 & 667 & 21867 & 1333 & 11867 & 533 & 10667 & 1467 & 7733 & 2000 & 12000 & 1867 & 7067 & 800 & 6133 & 1600 & 8000 & 667 & 6267 & 1067 \\
\hline Spirogyra sp. & 2000 & 133 & & & & & 667 & & 600 & 67 & & & 667 & & 667 & & 1733 & 667 & 1600 & & & \\
\hline Stigeoclonium sp. & 14667 & 400 & 7600 & 667 & 21600 & 1333 & 10933 & 400 & 9733 & 1000 & 7067 & 2000 & 7467 & 1733 & 6000 & 800 & 3600 & 933 & 4667 & 667 & 6000 & 867 \\
\hline Chaetophora sp. & & & & & & & & & 200 & & 267 & & 3733 & 133 & 267 & & & & & & & \\
\hline Desmid sp. & 133 & & & & & & & & & 267 & 267 & & & & & & & & & & & \\
\hline Ankistrodesmus sp. & & & & & & & & & & 67 & & & & & & & & & & & 267 & \\
\hline Peridinium sp. & & & 267 & & & & & & & 67 & & & & & & & & & & & & 200 \\
\hline Zygnema sp. & & & & & & & & & 133 & & & & & & & & & & & & & \\
\hline Pediastrum sp. & & & & & 267 & & 267 & 133 & & & & & & & & & & & & & & \\
\hline Ulotrhix sp. & & & & & & & & & & & 133 & & 133 & & 133 & & 800 & & 1733 & & & \\
\hline Chrysophyceae & 800 & 267 & 800 & 2400 & 933 & 267 & 533 & $\mathbf{0}$ & 200 & 267 & 667 & 267 & 800 & 133 & 533 & 133 & 2267 & 1733 & 1333 & 133 & 533 & 133 \\
\hline Cymbela sp. & & & & & & & & & 133 & & & & & & & & & & 267 & & & \\
\hline Navicula sp. & 267 & 133 & 133 & 400 & & 133 & 133 & & 67 & 67 & 400 & & 400 & & 267 & 133 & 1600 & 1467 & & 133 & 133 & 67 \\
\hline Gomphonema sp. & 133 & 133 & & 667 & 400 & 133 & 400 & & & 133 & 267 & 267 & 400 & & & & 133 & 133 & 800 & & & \\
\hline Synedra ulna & 267 & & & 667 & 267 & & & & & 67 & & & & & & & 400 & & & & 133 & \\
\hline Frustulia sp. & & & & 267 & 133 & & & & & & & & & 133 & & & 133 & & & & & 67 \\
\hline Melosira sp. & 133 & & 667 & 133 & 133 & & & & & & & & & & & & & & & & & \\
\hline Tabellaria sp. & & & & 267 & & & & & & & & & & & 133 & & & 133 & & & 133 & \\
\hline Nizschia sp. & & & & & & & & & & & & & & & 133 & & & & 267 & & & \\
\hline \begin{tabular}{|l} 
Surirella $\mathrm{sp}$. \\
\end{tabular} & & & & & & & & & & & & & & & & & & & & & 133 & \\
\hline Jumlah individu/dm² & 27200 & 1600 & 11600 & 3867 & 30800 & 2000 & 12800 & 1067 & 21267 & 2533 & 23200 & 8000 & 23600 & 4533 & 16267 & 1267 & 25733 & 8667 & 15333 & 1467 & \begin{tabular}{l|l}
15733 \\
\end{tabular} & 2267 \\
\hline
\end{tabular}




\begin{tabular}{|c|c|c|c|c|c|c|c|c|c|c|c|c|c|c|c|c|c|c|c|c|c|c|}
\hline Juli & \multicolumn{22}{|c|}{ Stasiun } \\
\hline Taxa & $1.1 \mathrm{~J}$ & $1.1 \mathrm{R}$ & $1.2 \mathrm{~J}$ & $1.2 \mathrm{R}$ & $1.3 \mathrm{~J}$ & $1.3 \mathrm{R}$ & $1.4 \mathrm{~J}$ & $1.4 \mathrm{R}$ & $1.5 \mathrm{~J}$ & $1.5 \mathrm{R}$ & $2.1 \mathrm{~J}$ & $2.1 \mathrm{R}$ & $2.2 \mathrm{~J}$ & $2.2 \mathrm{R}$ & $3.1 \mathrm{~J}$ & $3.1 \mathrm{R}$ & $4.1 \mathrm{~J}$ & $4.1 \mathrm{R}$ & $4.2 \mathrm{~J}$ & $4.2 \mathrm{R}$ & $5.2 \mathrm{~J}$ & $5.2 \mathrm{R}$ \\
\hline Cyanophyceae & 9067 & 933 & 24800 & 1867 & 3733 & 400 & 29867 & 3200 & 9333 & 400 & 38333 & 9867 & 4600 & 667 & 13867 & 1333 & 34133 & 3600 & 9467 & 1733 & 22667 & 5333 \\
\hline Oscillatoria limnetica & & & & & & & & & & & & 267 & 400 & & 1067 & 400 & & & 1067 & & & 267 \\
\hline Oscilatoria $\mathrm{sp}$. & & & & 267 & & 133 & & 400 & & 133 & 4000 & & 1200 & & & 133 & 2667 & 133 & & & & \\
\hline Lyngbya $\mathrm{sp}$. & 800 & 133 & 4800 & 533 & 1067 & & 3200 & 667 & 1000 & & 1667 & 1600 & & 400 & & & & & & & 267 & 267 \\
\hline Rivularia sp. & 8267 & 800 & 20000 & 1067 & 2667 & 267 & 26667 & 1200 & 8333 & 267 & 29667 & 8000 & & & 12533 & 667 & 29333 & 3333 & 7867 & 1600 & 22400 & 4800 \\
\hline Microcystis sp. & & & & & & & & & & & & & & & & & & & & 133 & & \\
\hline \multicolumn{23}{|l|}{ Spirulina sp. } \\
\hline Chroococcus sp. & & & & & & & & 800 & & & & & & & & & 267 & & & & & \\
\hline Anabaena sp. & & & & & & & & 133 & & & 3000 & & 2400 & 133 & 267 & & 1600 & & 533 & & & \\
\hline Nostoc sp. & & & & & & & & & & & & & 600 & 133 & & 133 & 267 & 133 & & & & \\
\hline Cholorophyceae & 33333 & 533 & 13333 & 2400 & 18400 & 267 & 7467 & 800 & 16333 & 667 & 18000 & 3467 & 12200 & 400 & 10400 & 533 & \begin{tabular}{|l|}
12267 \\
\end{tabular} & 2933 & 9867 & 1067 & 15467 & 1600 \\
\hline Spirogyra sp. & 11467 & 400 & 1067 & 933 & 10933 & 133 & 3467 & 267 & 1000 & 133 & 667 & 267 & & & 1333 & 133 & 3467 & 2133 & 267 & 133 & 13600 & 267 \\
\hline Stigeoclonium sp. & 7733 & 133 & 11733 & 1467 & 4800 & 133 & 4000 & 400 & 9000 & 400 & 17333 & 3200 & 4800 & 400 & 8267 & \begin{tabular}{l|l}
400 \\
\end{tabular} & 7200 & 800 & 9600 & 933 & 1333 & 1333 \\
\hline Chaetophora sp. & 13600 & & 533 & & 2667 & & & & 6333 & 133 & & & 7200 & & 533 & & & & & & & \\
\hline Desmid sp. & 533 & & & & & & & 133 & & & & & & & & & & & & & & \\
\hline Ankistrodesmus sp. & & & & & & & & & & & & & & & & & & & & & 533 & \\
\hline \multicolumn{23}{|l|}{ Peridinium sp. } \\
\hline \multicolumn{23}{|l|}{ Zygnema sp. } \\
\hline \multicolumn{23}{|l|}{ Pediastrum sp. } \\
\hline Ulotrhix sp. & & & & & & & & & & & & & 200 & & 267 & & 1600 & & & & & \\
\hline Chrysophyceae & 800 & 267 & 1333 & 400 & 3733 & 400 & 1333 & 1200 & 1000 & 267 & 1000 & 1600 & 800 & 400 & 267 & 6 667 & 1867 & 667 & 667 & 267 & 1067 & 2933 \\
\hline Cymbela sp. & & & & & & & 533 & & & & & & & & & & & & & & & \\
\hline Navicula sp. & 533 & 133 & & 267 & 1867 & 267 & 267 & 667 & 667 & 133 & 667 & & 200 & 267 & & \begin{tabular}{l|l}
533 \\
\end{tabular} & 533 & 267 & 667 & 267 & 267 & 2933 \\
\hline Gomphonema sp. & 267 & 133 & 533 & & 800 & 133 & 267 & 133 & & & 333 & 1333 & 600 & & 267 & 133 & 267 & 267 & & & & \\
\hline Synedra ulna & & & & & 1067 & & & & & & & 267 & & & & & 800 & & & & 267 & \\
\hline Frustulia $\mathrm{sp}$. & & & 800 & 133 & & & & & & & & & & 133 & & & 267 & 133 & & & & \\
\hline Melosira sp. & & & & & & & & 400 & & 133 & & & & & & & & & & & & \\
\hline Tabellaria sp. & & & & & & & & & & & & & & & & & & & & & 267 & \\
\hline Nizschia sp. & & & & & & & & & 333 & & & & & & & & & & & & & \\
\hline Surirella sp. & & & & & & & 267 & & & & & & & & & & & & & & 267 & \\
\hline Jumlah individu/dm² & 43200 & 1733 & 39467 & 4667 & 25867 & 1067 & 38667 & 5200 & 26667 & 1333 & 57333 & 14933 & 17600 & 1467 & 24533 & \begin{tabular}{|l|l|}
2533 \\
\end{tabular} & 48267 & 7200 & 20000 & 3067 & 39200 & 9867 \\
\hline
\end{tabular}



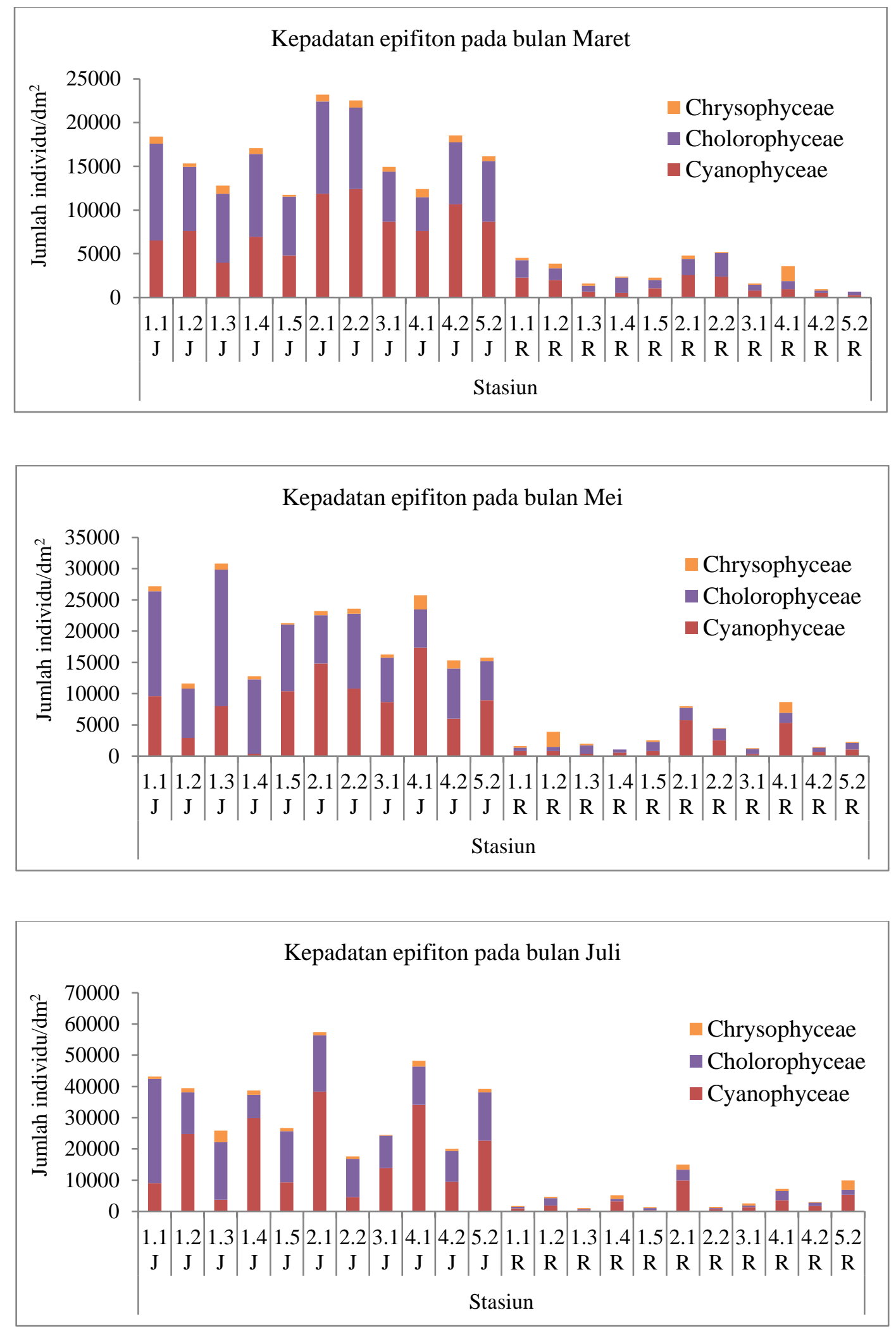

Gambar 2. Kepadatan ketiga kelas mikroalga epifiton yang diamati selama penelitian

Kelimpahan kelas Cyanophyceae jauh lebih tinggi daripada Chlorophyceae dan Chrysophyceae pada kondisi vegetasi jarang
(Gambar 2). Peningkatan kelimpahan Cyanophyceae sangat signifikan terjadi pada bulan Juli dibandingkan bulan Maret dan Mei di lima 
stasiun dengan vegetasi jarang dan di tiga stasiun dengan vegetasi rapat. Kelimpahan kelas Chlorophyceae pada kondisi vegetasi jarang juga lebih tinggi pada bulan Juli daripada bulan Maret dan Mei, kecuali di dua stasiun. Sebaliknya, kelimpahannya pada kondisi vegetasi rapat di semua stasiun sangat rendah dengan kelimpahan tertinggi ditemui di Stasiun 2.1R pada bulan Juli sebanyak 3.467 individu/ $\mathrm{dm}^{2}$. Kelimpahan kelas Chrysophyceae yang pada umumnya jauh lebih rendah dibandingkan kedua kelas yang lain tidak menunjukkan pola yang jelas dari bulan Maret, Mei, hingga Juli. Ada lima stasiun di vegetasi jarang dan empat stasiun di vegetasi rapat yang tidak menunjukkan kenaikan kelimpahan pada bulan Juli. Namun, ada 10 stasiun di kedua tipe vegetasi yang menunjukkan kenaikan kelimpahan yang signifikan pada bulan Juli (Gambar 2).

Analisis perbedaan kelimpahan epifiton antara vegetasi jarang dan vegetasi rapat selama penelitian menunjukkan bahwa terdapat perbedaan kelimpahan yang signifikan $(P<$ $0,05)$ antara epifiton di vegetasi rapat dan di vegetasi jarang (Gambar 3). Perbedaan waktu pengambilan sampel (Maret, Mei, Juli) tidak berpengaruh terhadap kelimpahan epifiton di sesama vegetasi rapat. Namun, di sesama vegetasi jarang antara bulan Maret dan Juli serta antara bulan Mei dan Juli kelimpahan epifiton menunjukkan perbedaan yang signifikan $(P<0,05)$

Nilai indeks keanekaragaman jenis Shannon-Wiener $(\mathrm{H})$ berkisar 1,16-2,00 (Maret), 0,67-2,21 (Mei), dan 1,03-2,18 (Juli) yang menunjukkan bahwa tingkat keanekaragaman spesies epifiton di Danau Tempe selama penelitian termasuk rendah (Tabel 3a). Nilai indeks kemerataan jenis Pielou (E) berkisar 0,27-0,96 (Maret), 0,22-0,87 (Mei), 0,22-0,93 (Juli) yang menunjukkan bahwa stasiun bervegetasi jarang memiliki kemerataan spesies yang rendah, artinya jumlah individu yang dimiliki masing-masing spesies cukup berbeda. Sebaliknya, stasiun bervegetasi rapat memiliki kemerataan spesies sedang hingga tinggi yang berarti spesies relatif merata atau jumlah individu masing-masing spesies relatif sama (Tabel 3b). Nilai indeks dominansi Simpson (D) berkisar 0,18-0,47 (Maret), 0,130,55 (Mei), 0,13-0,50 (Juli) yang menunjukkan bahwa dominansi spesies hanya terjadi pada stasiun 1.4J dan 2.1R pada bulan Mei (Tabel 3c). Pengukuran dominansi (d) menggunakan indeks Berger-Parker dengan nilai berkisar 0,26-0,67 (Maret), 0,17-0,85 (Mei), 0,23-0,69 (Juli) menunjukkan bahwa dominansi spesies terjadi di sejumlah stasiun pengamatan bahkan pada stasiun $1.4 \mathrm{~J}$ dan $4.1 \mathrm{~J}$ dominansi spesies terjadi sepanjang pengamatan (Tabel 3d). Kekayaan jenis berkisar 4-12 (Maret), 4-13 (Mei), 5-12 (Juli) dengan nilai minimum ditemukan di stasiun bervegetasi rapat dan nilai maksimum di stasiun bervegetasi jarang.

Kualitas fisika-kima air Danau Tempe selama penelitian diperlihatkan dalam Tabel 4 . Nilai pH berkisar 6,76-8,37 (Maret), 6,60-8,61 (Mei), 7,31-8,30 (Juli). Kisaran pH yang optimal untuk kehidupan biota air adalah 6,59,0 (Wetzel, 1983). Suhu air berkisar 30,39$32,71^{\circ} \mathrm{C}$ (Maret), $27,2-31,6^{\circ} \mathrm{C}$ (Mei), dan $27,8-$ $29,5^{\circ} \mathrm{C}$ (Juli) yang menunjukkan terjadi penurunan suhu air rata-rata selama penelitian. Hal ini kemungkinan disebabkan musim hujan yang berlangsung sejak bulan Mei. Konsentrasi oksigen terlarut (DO) berkisar 5,84-10,30 mg/L (Maret), 1,85-8,80 mg/L (Mei), 2,56-8,22 $\mathrm{mg} / \mathrm{L}$ (Juli). Danau yang sehat memiliki kandungan DO yang berkisar $5-9 \mathrm{mg} / \mathrm{L}$ atau minimum $4 \mathrm{mg} / \mathrm{L}$ untuk mampu mendukung berbagai populasi ikan (Aquaculture SA, 2003, PP No. 82 Tahun 2001).

Nilai turbiditas untuk semua stasiun selama penelitian (Tabel 4) sudah melewati ambang batas yang dianjurkan oleh US EPA untuk perikanan yaitu 25 NTU, kecuali di Stasiun 5.2 pada bulan Maret (17 NTU).

Konduktivitas berkisar 0,122-0,277 $\mathrm{mS} / \mathrm{cm}$ (Maret), 0,158-0,317 mS/cm (Mei), 0,112-0,156 mS/cm (Juli). Konsentrasi fosfat selama penelitian berada di bawah ambang batas yang aman untuk perikanan, yaitu 0,5 $\mathrm{mg} / \mathrm{L}$ (EPA, 2001).

Grafik diplot dan konfirmasi hasil variable loading program MVSP (Gambar 3) menunjukkan bahwa kedua kelompok zona vegetasi jarang dan vegetasi rapat berada pada sumbu satu, meskipun rentang zona vegetasi jarang cukup terpisah dari zona vegetasi rapat.

Grafik ini juga menunjukkan bahwa pengaruh vegetasi jarang terhadap kelimpahan mikroalga epifiton lebih kuat daripada vegetasi rapat di hampir semua titik pengamatan. Dengan demikian, kelimpahan mikroalga epifiton yang tinggi di Danau Tempe berkaitan erat dengan substrat vegetasi jarang. Selain itu, 
Tabel 3. Nilai indeks Shannon-Wiener (H), Indeks Pielou (E), indeks Simpson (D), indeks Berger-Parker, dan kekayaan jenis pada kedua tipe substrat J dan R dari setiap stasiun pada bulan Maret, Mei, dan Juli 2017

a. Indeks Shannon-Wiener $(\mathrm{H})$

\begin{tabular}{|c|c|c|c|c|c|c|c|c|c|c|c|c|c|c|c|c|c|c|c|c|c|c|}
\hline \multicolumn{23}{|c|}{ Stasiun } \\
\hline & $1.1 \mathrm{~J}$ & $1.1 \mathrm{R}$ & $1.2 \mathrm{~J}$ & $1.2 \mathrm{R}$ & $1.3 \mathrm{~J}$ & $1.3 \mathrm{R}$ & $1.4 \mathrm{~J}$ & $1.4 \mathrm{R}$ & $1.5 \mathrm{~J}$ & $1.5 \mathrm{R}$ & $2.1 \mathrm{~J}$ & $2.1 \mathrm{R}$ & $2.2 \mathrm{~J}$ & $2.2 \mathrm{R}$ & $3.1 \mathrm{~J}$ & $3.1 \mathrm{R}$ & $4.1 \mathrm{~J}$ & $4.1 \mathrm{R}$ & $4.2 \mathrm{~J}$ & $4.2 \mathrm{R}$ & $5.2 \mathrm{~J}$ & $5.2 \mathrm{R}$ \\
\hline Mar & 1,57 & 1,48 & 1,35 & 1,50 & 1,28 & 1,70 & 1,28 & 1,16 & 1,60 & 2,00 & 1,65 & 1,65 & 1,65 & 1,43 & 1,38 & 1,48 & 1,34 & 1,47 & 1,26 & 1,75 & 1,39 & 1,31 \\
\hline Mei & 1,37 & 1,54 & 1,23 & 2,21 & 1,00 & 1,08 & 0,67 & 1,49 & 1,61 & 1,88 & 1,38 & 0,78 & 1,64 & 1,35 & 1,35 & 1,16 & 1,54 & 1,48 & 1,84 & 1,54 & 1,04 & 1,25 \\
\hline Jul & 1,55 & 1,48 & 1,25 & 1,70 & 1,71 & 1,73 & 1,08 & 2,18 & 1,46 & 1,83 & 1,28 & 1,34 & 1,59 & 1,67 & 1,23 & 1,88 & 1,39 & 1,43 & 1,14 & 1,19 & 1,03 & 1,27 \\
\hline
\end{tabular}

b. Indeks Pielou (E)

\begin{tabular}{|c|c|c|c|c|c|c|c|c|c|c|c|c|c|c|c|c|c|c|c|c|c|c|}
\hline \multicolumn{23}{|c|}{ Stasiun } \\
\hline & $1.1 \mathrm{~J}$ & $1.1 \mathrm{R}$ & $1.2 \mathrm{~J}$ & $1.2 \mathrm{R}$ & $1.3 \mathrm{~J}$ & $1.3 \mathrm{R}$ & $1.4 \mathrm{~J}$ & $1.4 \mathrm{R}$ & $1.5 \mathrm{~J}$ & $1.5 \mathrm{R}$ & $2.1 \mathrm{~J}$ & $2.1 \mathrm{R}$ & $2.2 \mathrm{~J}$ & $2.2 \mathrm{R}$ & $3.1 \mathrm{~J}$ & $3.1 \mathrm{R}$ & $4.1 \mathrm{~J}$ & $4.1 \mathrm{R}$ & $4.2 \mathrm{~J}$ & $4.2 \mathrm{R}$ & $5.2 \mathrm{~J}$ & $5.2 \mathrm{R}$ \\
\hline Mar & 0,30 & 0,47 & 0,29 & 0,49 & 0,33 & 0,80 & 0,30 & 0,56 & 0,29 & 0,62 & 0,32 & 0,50 & 0,33 & 0,43 & 0,33 & 0,64 & 0,34 & 0,54 & 0,27 & 0,96 & 0,30 & 0,86 \\
\hline Mei & 0,22 & 0,74 & 0,37 & 0,74 & 0,22 & 0,57 & 0,29 & 0,87 & 0,24 & 0,55 & 0,26 & 0,27 & 0,31 & 0,42 & 0,31 & 0,62 & 0,29 & 0,40 & 0,52 & 0,78 & 0,24 & 0,40 \\
\hline Jul & 0,26 & 0,70 & 0,30 & 0,63 & 0,62 & 0,93 & 0,24 & 0,69 & 0,36 & 0,89 & 0,27 & 0,36 & 0,37 & 0,84 & 0,29 & 0,73 & 0,28 & 0,38 & 0,32 & 0,49 & 0,22 & 0,38 \\
\hline
\end{tabular}

c. Indeks Simpson (D)

\begin{tabular}{|c|c|c|c|c|c|c|c|c|c|c|c|c|c|c|c|c|c|c|c|c|c|c|}
\hline & \multicolumn{22}{|c|}{ Stasiun } \\
\hline & $1.1 \mathrm{~J}$ & $1.1 \mathrm{R}$ & $1.2 \mathrm{~J}$ & $1.2 \mathrm{R}$ & $1.3 \mathrm{~J}$ & $1.3 \mathrm{R}$ & $1.4 \mathrm{~J}$ & $1.4 \mathrm{R}$ & $1.5 \mathrm{~J}$ & $1.5 \mathrm{R}$ & $2.1 \mathrm{~J}$ & $2.1 \mathrm{R}$ & $2.2 \mathrm{~J}$ & $2.2 \mathrm{R}$ & $3.1 \mathrm{~J}$ & $3.1 \mathrm{R}$ & $4.1 \mathrm{~J}$ & $4.1 \mathrm{R}$ & $4.2 \mathrm{~J}$ & $4.2 \mathrm{R}$ & $5.2 \mathrm{~J}$ & $5.2 \mathrm{R}$ \\
\hline Mar & 0,278 & 0,303 & 0,355 & 0,301 & 0,411 & 0,236 & 0,384 & 0,469 & 0,302 & 0,185 & 0,273 & 0,272 & 0,276 & 0,339 & 0,361 & 0,281 & 0,388 & 0,276 & 0,385 & 0,184 & 0,344 & 0,280 \\
\hline Mei & 0,352 & 0,264 & 0,455 & 0,125 & 0,524 & 0,476 & 0,734 & 0,250 & 0,280 & 0,219 & 0,330 & 0,554 & 0,264 & 0,346 & 0,358 & 0,435 & 0,358 & 0,339 & 0,197 & 0,273 & 0,441 & 0,351 \\
\hline Jul & 0,239 & 0,290 & 0,361 & 0,211 & 0,244 & 0,188 & 0,502 & 0,132 & 0,272 & 0,180 & 0,368 & 0,353 & 0,268 & 0,207 & 0,380 & 0,175 & 0,403 & 0,318 & 0,390 & 0,376 & 0,448 & 0,346 \\
\hline
\end{tabular}




\section{d. Indeks Berger-Parker}

\begin{tabular}{|c|c|c|c|c|c|c|c|c|c|c|c|c|c|c|c|c|c|c|c|c|c|c|}
\hline \multicolumn{23}{|c|}{ Stasiun } \\
\hline & $1.1 \mathrm{~J}$ & $1.1 \mathrm{R}$ & $1.2 \mathrm{~J}$ & $1.2 \mathrm{R}$ & $1.3 \mathrm{~J}$ & $1.3 \mathrm{R}$ & $1.4 \mathrm{~J}$ & $1.4 \mathrm{R}$ & $1.5 \mathrm{~J}$ & $1.5 \mathrm{R}$ & $2.1 \mathrm{~J}$ & $2.1 \mathrm{R}$ & $2.2 \mathrm{~J}$ & $2.2 \mathrm{R}$ & $3.1 \mathrm{~J}$ & $3.1 \mathrm{R}$ & $4.1 \mathrm{~J}$ & $4.1 \mathrm{R}$ & $4.2 \mathrm{~J}$ & $4.2 \mathrm{R}$ & $5.2 \mathrm{~J}$ & $5.2 \mathrm{R}$ \\
\hline Mar & 0,399 & 0,382 & 0,443 & 0,414 & 0,583 & 0,417 & 0,508 & 0,667 & 0,494 & 0,353 & 0,431 & 0,361 & 0,444 & 0,487 & 0,509 & 0,417 & 0,548 & 0,259 & 0,525 & 0,286 & 0,446 & 0,300 \\
\hline Mei & 0,539 & 0,417 & 0,655 & 0,172 & 0,701 & 0,667 & 0,854 & 0,375 & 0,458 & 0,395 & 0,471 & 0,700 & 0,367 & 0,441 & 0,467 & 0,632 & 0,570 & 0,538 & 0,304 & 0,455 & 0,542 & 0,441 \\
\hline Jul & 0,315 & 0,462 & 0,507 & 0,314 & 0,423 & 0,250 & 0,690 & 0,231 & 0,338 & 0,300 & 0,517 & 0,536 & 0,409 & 0,273 & 0,511 & 0,263 & 0,608 & 0,463 & 0,480 & 0,522 & 0,571 & 0,486 \\
\hline
\end{tabular}

e. Kekayaan jenis (species richness)

\begin{tabular}{ccccccccccccccccccccccc}
\hline \multicolumn{110}{c}{ Stasiun } \\
\hline & $1.1 \mathrm{~J}$ & $1.1 \mathrm{R}$ & $1.2 \mathrm{~J}$ & $1.2 \mathrm{R}$ & $1.3 \mathrm{~J}$ & $1.3 \mathrm{R}$ & $1.4 \mathrm{~J}$ & $1.4 \mathrm{R}$ & $1.5 \mathrm{~J}$ & $1.5 \mathrm{R}$ & $2.1 \mathrm{~J}$ & $2.1 \mathrm{R}$ & $2.2 \mathrm{~J}$ & $2.2 \mathrm{R}$ & $3.1 \mathrm{~J}$ & $3.1 \mathrm{R}$ & $4.1 \mathrm{~J}$ & $4.1 \mathrm{R}$ & $4.2 \mathrm{~J}$ & $4.2 \mathrm{R}$ & $5.2 \mathrm{~J}$ & $5.2 \mathrm{R}$ \\
\hline Mar & 12 & 8 & 12 & 8 & 11 & 7 & 11 & 6 & 12 & 11 & 12 & 10 & 12 & 9 & 11 & 6 & 12 & 6 & 10 & 6 & 11 & 4 \\
\hline Mei & 10 & 6 & 8 & 11 & 9 & 5 & 8 & 5 & 12 & 11 & 9 & 4 & 12 & 8 & 11 & 5 & 13 & 9 & 9 & 6 & 9 & 6 \\
\hline Jul & 8 & 6 & 7 & 7 & 8 & 6 & 8 & 11 & 7 & 7 & 8 & 7 & 9 & 6 & 8 & 8 & 12 & 8 & 6 & 5 & 9 & 6 \\
\hline
\end{tabular}


Tabel 4. Kualitas fisika-kima air Danau Tempe pada bulan Maret, Mei, dan Juli 2017

\begin{tabular}{|c|c|c|c|c|c|c|c|c|c|}
\hline Waktu & Stasiun & $\mathrm{pH}$ & $\begin{array}{c}\text { Suhu } \\
\left({ }^{\circ} \mathrm{C}\right)\end{array}$ & $\begin{array}{c}\mathrm{DO} \\
(\mathrm{mg} / \mathrm{L})\end{array}$ & $\begin{array}{l}\text { Konduk. } \\
(\mathrm{mS} / \mathrm{cm})\end{array}$ & $\begin{array}{l}\text { Turbid. } \\
\text { (NTU) }\end{array}$ & $\begin{array}{c}\mathrm{TN} \\
(\mathrm{mg} / \mathrm{L})\end{array}$ & $\begin{array}{c}\mathrm{TP} \\
(\mathrm{mg} / \mathrm{L})\end{array}$ & $\begin{array}{l}\mathrm{P}-\mathrm{PO}_{4} \\
(\mathrm{mg} / \mathrm{L})\end{array}$ \\
\hline \multirow{11}{*}{ Maret } & 1.1 & 6,76 & 31 & 6 & 0,253 & 33 & 1,027 & 0,137 & 0,100 \\
\hline & 1.2 & 7,12 & 31 & 7 & 0,184 & 58 & 0,662 & 0,221 & 0,083 \\
\hline & 1.3 & 7,33 & 33 & 10 & 0,191 & 34 & 0,753 & 0,066 & 0,019 \\
\hline & 1.4 & 7,22 & 30 & 10 & 0,180 & 35 & 0,671 & 0,117 & 0,076 \\
\hline & 1.5 & 7,29 & 31 & 8 & 0,170 & 116 & 0,970 & 0,120 & 0,087 \\
\hline & 2.1 & 8,37 & 32 & 8 & 0,122 & 58 & 0,678 & 0,095 & 0,060 \\
\hline & 2.2 & 7,77 & 31 & 9 & 0,174 & 79 & 0,843 & 0,104 & 0,062 \\
\hline & 3.1 & 7,82 & 31 & 9 & 0,184 & 147 & 0,632 & 0,122 & 0,082 \\
\hline & 4.1 & 7,99 & 31 & 7 & 0,173 & 95 & 0,829 & 0,112 & 0,068 \\
\hline & 4.2 & 6,97 & 31 & 6 & 0,167 & 25 & 0,208 & 0,088 & 0,010 \\
\hline & 5.2 & 6,98 & 32 & 6 & 0,277 & 17 & 0,765 & 0,053 & 0,010 \\
\hline \multirow{11}{*}{ Mei } & 1.1 & 6,60 & 28,3 & 5,3 & 0,25 & 126 & 0,694 & 0,218 & 0,118 \\
\hline & 1.2 & 8,20 & 29,6 & 7,6 & 0,22 & 135 & 0,535 & 0,11 & 0,017 \\
\hline & 1.3 & 7,55 & 31,5 & 7,6 & 0,32 & 42 & 0,481 & 0,162 & 0,069 \\
\hline & 1.4 & 8,61 & 30,8 & 8,8 & 0,26 & 81 & 0,583 & 0,092 & 0,014 \\
\hline & 1.5 & 7,96 & 31,0 & 7,0 & 0,20 & 127 & 0,395 & 0,159 & 0,049 \\
\hline & 2.1 & 7,17 & 31,6 & 6,9 & 0,21 & 120 & 0,533 & 0,127 & 0,06 \\
\hline & 2.2 & 6,75 & 30,5 & 8,3 & 0,21 & 139 & 0,285 & 0,127 & 0,095 \\
\hline & 3.1 & 7,12 & 30,0 & 6,4 & 0,23 & 111 & 0,299 & 0,195 & 0,125 \\
\hline & 4.1 & 7,26 & 29,7 & 7,3 & 0,18 & 93 & 0,156 & 0,211 & 0,045 \\
\hline & 4.2 & 7,31 & 28,6 & 3,5 & 0,16 & 224 & 0,278 & 0,104 & 0,014 \\
\hline & 5.2 & 7,24 & 27,2 & 1,9 & 0,20 & 628 & 0,492 & 0,169 & 0,055 \\
\hline \multirow{11}{*}{ Juli } & 1.1 & 8,09 & 28,0 & 7,5 & 0,141 & 92 & 0,644 & 0,062 & 0,019 \\
\hline & 1.2 & 8,30 & 27,9 & 8,2 & 0,134 & 120 & 0,348 & 0,061 & 0,02 \\
\hline & 1.3 & 7,31 & 27,8 & 2,6 & 0,140 & 35 & 0,366 & 0,086 & 0,058 \\
\hline & 1.4 & 7,69 & 28,1 & 6,4 & 0,141 & 50 & 0,195 & 0,101 & 0,048 \\
\hline & 1.5 & 7,93 & 28,4 & 6,9 & 0,117 & 42 & 1,914 & 0,095 & 0,048 \\
\hline & 2.1 & 7,55 & 29,5 & 6,1 & 0,133 & 42 & 0,836 & 0,083 & 0,028 \\
\hline & 2.2 & 7,55 & 28,8 & 4,1 & 0,156 & 239 & 1,752 & 0,269 & 0,152 \\
\hline & 3.1 & 7,40 & 28,2 & 3,7 & 0,112 & 121 & 1,508 & 0,135 & 0,097 \\
\hline & 4.1 & 7,63 & 28,4 & 4,6 & 0,120 & 67 & 1,721 & 0,068 & 0,025 \\
\hline & 4.2 & 8,09 & 28,5 & 7,7 & 0,120 & 65 & 1,844 & 0,062 & 0,019 \\
\hline & 5.2 & 7,72 & 29,3 & 6,4 & 0,131 & 39 & 1,153 & 0,057 & 0,010 \\
\hline
\end{tabular}

zona vegetasi jarang dicirikan oleh epifiton Stigeoclonium sp. (Stasiun 1.1, 1.3, dan 1.5) dan Rivularia sp. (Stasiun 1.4 dan 4.1) sebagai komponen utama.

Selain kondisi kerapatan yang berkaitan langsung dengan ketersediaan cahaya, hasil ordinasi tidak langsung antara komposisi jenis epifiton dan variabel kualitas air menunjukkan bahwa epifiton Stigeoclonium sp. sangat dipengaruhi oleh konsentrasi fosfat, TP, dan konduktivitas, sedangkan Rivularia sp. sangat dipengaruhi oleh $\mathrm{pH}$ dan TN (Gambar 4). 


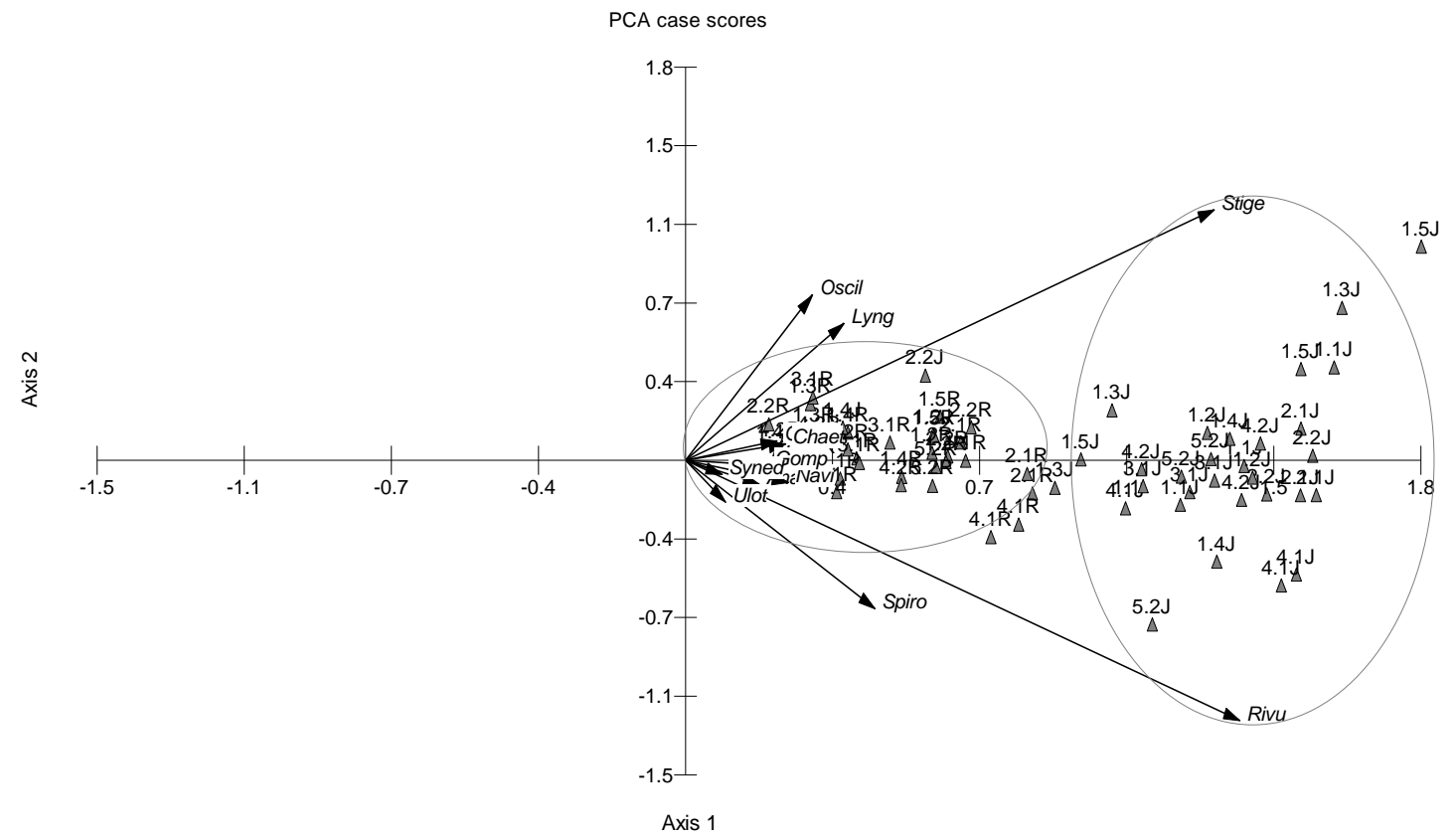

Vector scaling: 2.10

Gambar 3. Grafik diplot komposisi jenis mikroalga epifiton pada kondisi vegetasi rapat dan jarang dalam Principal Component Analysis dengan software MVSP versi 3.1

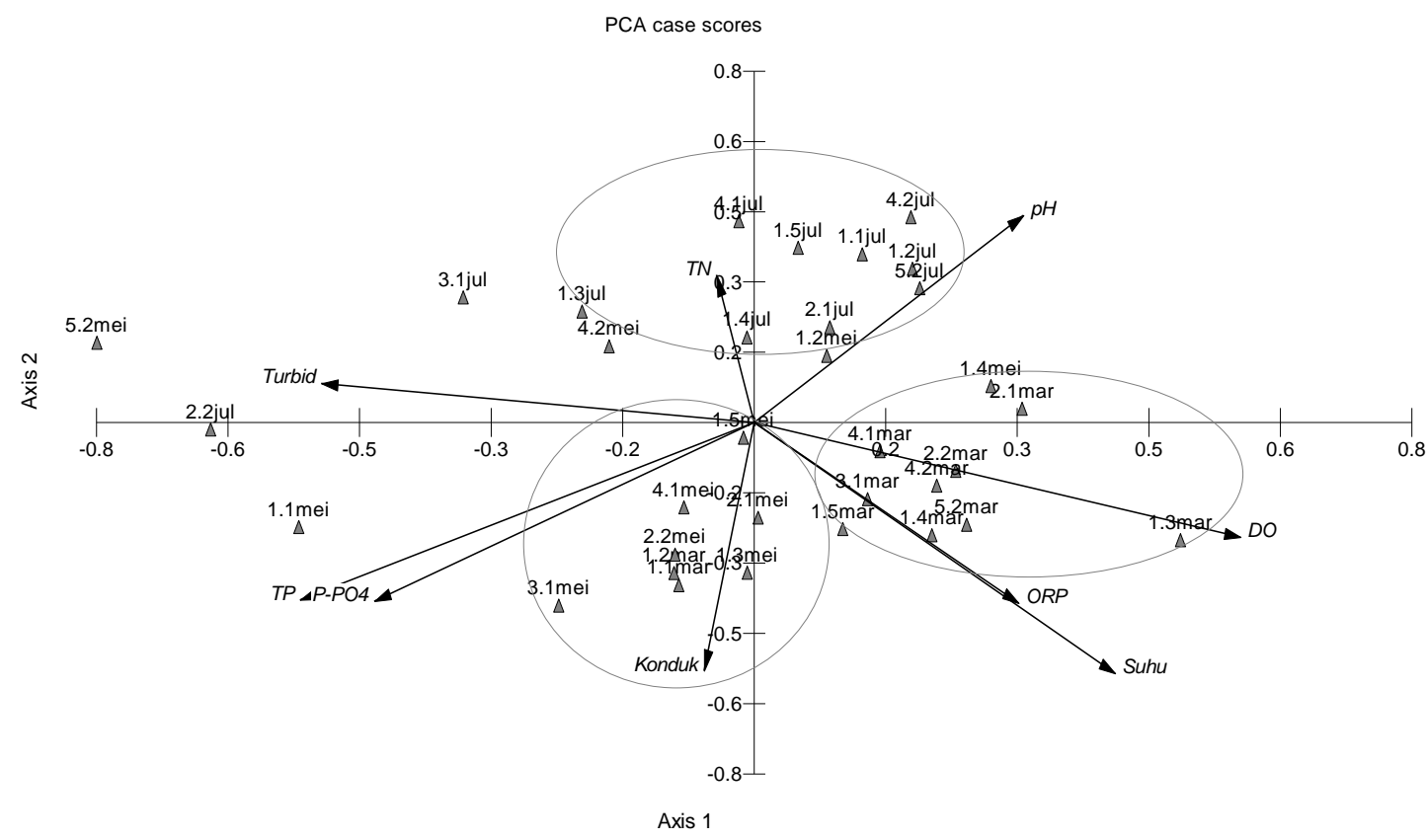

Vector scaling: 1.25

Gambar 4. Grafik diplot kondisi fisika kimia air di setiap stasiun pengamatan dengan Principal Component Analysis 


\section{Pembahasan}

Kelimpahan mikroalga epifiton yang lebih tinggi pada substrat vegetasi jarang dibanding vegetasi rapat (Gambar 2) menandakan bahwa cahaya merupakan faktor penting bagi pertumbuhan epifiton.

Kerapatan tumbuh makrofita sangat berpengaruh pada kelimpahan populasi epifiton. Di danau dangkal yang didominasi oleh makrofita, fitur makrofita sebagai substrat bagi epifiton juga membatasi pertumbuhan dan kelimpahan epifiton, terutama efek naungan dari makrofita itu sendiri (Öterler, 2017). Kerapatan makrofita yang tinggi akan membatasi penetrasi cahaya, sehingga menciptakan lingkungan yang teduh karena terjadi penurunan intensitas cahaya. Apabila diiringi dengan struktur batang silinder yang sederhana, hal ini akan memberikan lingkungan yang kurang menguntungkan bagi epifiton. Akibatnya, biomassa epifiton menjadi lebih rendah pada vegetasi yang tumbuh rapat dibandingkan vegetasi yang tumbuh jarang.

Makrofita yang tumbuh rapat dapat mengakumulasi sedimen dan bagian tumbuhan yang membusuk, menciptakan kondisi dengan konduktivitas listrik dan kekeruhan yang tinggi, serta oksigen yang rendah, yang umumnya tidak cocok untuk kehidupan ikan, makroinvertebrata, dan mikroalgae (Pettit et al., 2016). Namun, pada kondisi cahaya rendah epifiton mampu menghambat pertumbuhan makrofita dan kolonisasi jangka panjang oleh epifiton mengakibatkan perubahan morfologi pada makrofita tersebut (Sultana et al., 2010).

Kelimpahan epifiton pada kedua tipe vegetasi antara bulan Maret dan Juli serta antara bulan Mei dan Juli menunjukkan perbedaan yang signifikan $(P<0,05)$. Hal ini kemungkinan terkait dengan puncak musim hujan pada bulan Juli yang menyebabkan kandungan nutrien yang terbawa masuk menjadi lebih tinggi.

Hal menarik yang terjadi pada epifiton yaitu kelimpahan populasinya cenderung meningkat pada bulan Mei dan Juli, baik di lingkungan vegetasi jarang maupun vegetasi rapat (Gambar 2). Epifiton hidup menempel pada substrat makrofita, oleh karena itu faktor pengenceran yang terjadi selama musim hujan kemungkinan tidak terlalu berpengaruh pada kelimpahannya. Penambahan suplai nutrien dan volume air kelihatannya merupakan kondisi yang menguntungkan bagi pertumbuhan mikroalga epifiton pada bulan Mei dan Juli.

Selama musim hujan, suhu yang cukup tinggi dan tingkat nutrien yang juga tinggi akan meningkatkan pertumbuhan epifiton pada makrofita (Pettit et al., 2016). Kelimpahan kelas Cyanophyceae ditemukan lebih tinggi pada bulan Juli daripada bulan yang lain. Hasil ini sesuai dengan pernyataan Blanco et al. (2008) bahwa penambahan nutrien berdampak pada peningkatan kelimpahan epifiton Cyanophyceae (Cyanobacteria).

Secara ekologis, Cyanobacteria atau ganggang hijau biru adalah mikroflora fotoautotrofik yang paling penting dan dominan dalam hal biomassa total dan produktivitas, baik di laut, air tawar, maupun ekosistem terestrial. Cyanobacteria bisa ditemui di manamana di alam mulai dari sumber air panas hingga ke daerah Kutub Utara dan Antartika, serta di lingkungan ekstrem lain dengan salinitas, $\mathrm{pH}$, dan radiasi yang tinggi, dan bisa juga ditemukan dalam bentuk endosimbion pada tumbuhan, lumut dan beberapa Protista (Pentecost \& Whitton, 2012).

Peningkatan kandungan nutrien yang sangat tinggi dalam perairan akan meningkatkan pertumbuhan epifiton. Bila hal ini berlangsung cukup lama, radiasi cahaya yang diterima oleh permukaan makrofita akan terhambat karena terhalang oleh biomassa epifiton. Akibatnya, produktivitas primer perairan tersebut akan menurun drastis karena penurunan populasi makrofita, meskipun pertumbuhan fitoplankton dan epifiton meningkat (Twilley et al., 1985),

Morfologi spesies makrofita tertentu, terutama batang dan bentuk daun, dapat memengaruhi komposisi dan kelimpahan epifiton (Messyasz et al., 2009; Chung \& Lee, 2008). Menurut Santos et al. (2018), struktur taksonomi mikroalga sangat ditentukan oleh tipe substratnya. Selain itu, berbagai makrofita dengan karakteristik morfologi yang berbedabeda akan menempelkan epifiton yang berbedabeda pula struktur populasinya (Messyasz \& Rybak, 2009).

Di Danau Tempe, kelimpahan dan keanekaragaman mikroalga epifiton antara stasiun, baik pada substrat vegetasi rapat maupun jarang tidak menunjukkan perbedaan yang signifikan $(P>0,05)$. Dengan demikian, pemilihan jenis makrofita dan pengaturan kerapatan makrofita yang ideal di Danau Tempe 
merupakan faktor yang sangat penting untuk mendapatkan kelimpahan mikroalga epifiton yang optimum, terutama dalam penataan kawasan perikanan dengan produktivitas tinggi.

Nilai indeks keanekaragaman jenis Shannon-Wiener (H) menunjukkan tingkat keanekaragaman spesies dalam suatu komunitas. Keanekaragaman spesies di suatu lokasi bergantung pada jumlah spesies yang diamati (species richness) dan jumlah total individunya. Nilai $\mathrm{H}$ umumnya berkisar antara 0 dan 5 dengan tingkat keanekaragaman tinggi jika $\mathrm{H}>3$, sedang jika $2 \leq \mathrm{H} \leq 3$, dan rendah jika $0<\mathrm{H}<2$. Nilai $\mathrm{H}$ hasil penelitian ini berkisar 1,16-2,00 pada bulan Maret; 0,67-2,21 pada bulan Mei, dan 1,03-2,18 pada bulan Juli (Tabel 3a), yang menunjukkan bahwa tingkat keanekaragaman spesies epifiton selama penelitian pada umumnya rendah, kecuali di beberapa stasiun seperti 1.5R $(\mathrm{H}=2,00), 1.2 \mathrm{R}$ $(\mathrm{H}=2,21)$, dan di $1.4 \mathrm{R}(\mathrm{H}=2,18)$ yang memiliki keanekaragaman spesies sedang. Tabel 3a juga menunjukkan bahwa intensitas cahaya yang tinggi (dalam penelitian ini > 10.752 lux) tidak otomatis meningkatkan keanekaragaman spesies epifiton. Namun, Tabel 3e memperlihatkan bahwa kekayaan spesies dipengarui oleh kerapatan makrofita. Jadi, secara tidak langsung intensitas cahaya merupakan faktor yang memengaruhi keanekaragaman spesies epifiton.

Nilai indeks kemerataan jenis (E) umumnya berkisar dari 0 hingga 1 . Nilai $\mathrm{E}<$ 0,4 menunjukkan kemerataan spesies rendah, $0,4 \leq \mathrm{E} \leq 0,6$ menunjukkan kemerataan spesies sedang, dan $\mathrm{E}>0,6$ menunjukkan kemerataan spesies tinggi. Kemerataan mengacu pada kelimpahan relatif spesies. Nilai indeks kemerataan akan tinggi jika semua spesies memiliki distribusi yang mirip, misalnya kepadatan populasi yang serupa.

Nilai E hasil penelitian ini berkisar 0,2731-0,9576 pada bulan Maret; 0,21680,8688 pada bulan Mei, dan 0,2158-0,9323 pada bulan Juli (Tabel 3b). Untuk semua lokasi, nilai E pada vegetasi rapat selalu lebih tinggi daripada vegetasi jarang. Hal ini menunjukkan bahwa sebaran spesies epifiton lebih merata di lokasi dengan intensitas cahaya yang rendah ( $<10.752$ lux). Dengan demikian, ketersediaan cahaya yang cukup bersama-sama dengan nutrien dan keberadaan biota herbivora merupakan faktor penting yang mengendalikan biomassa epifiton dalam air yang dangkal atau tidak mengalir seperti halnya danau paparan banjir (Pettit et al., 2016). Kedua nilai indeks di atas menunjukkan bahwa intensitas cahaya yang tinggi (>10.752 lux) kemungkinan bisa menghambat pertumbuhan spesies epifiton tertentu.

Nilai indeks dominansi menurut Simpson (Tabel 3c) mencerminkan kondisi komunitas epifiton di perairan Danau Tempe yang seragam dan stabil, meskipun ada terjadi dominansi spesies di sebagian stasiun. Indeks dominansi ini dipertegas oleh hasil penghitungan menurut Berger-Parker (Tabel 3d), bahwa dominansi spesies terjadi di Stasiun 1.2J (Mei, Jul), 1.3J (Mar, Mei), 1.3R (Mei), 1.4J (Mar, Mei, Jul), 1.4R (Mei), 2.1J (Jul), 3.1J (Mar, Jul), 3.1R (Mei), 4.1J (Mar, Mei, Jul), dan 5.2J (Mei, Jul). Nilai ini menunjukkan bahwa selama pengamatan selalu ada spesies yang dominan sesuai kondisi ekosistem yang sudah dipengaruhi oleh aktivitas antropogenik (Caruso et al., 2007). Hal ini didukung oleh Tabel 2 yang memperlihatkan bahwa Rivularia sp. dan Stigeoclonium sp. merupakan dua spesies yang paling dominan selama penelitian di hampir seluruh stasiun. Pada bulan Juli di beberapa stasiun Spirogyra sp., dan Chaetophora sp. juga termasuk ke dalam spesies dominan, selain Rivularia sp. dan Stigeoclonium sp. Dengan demikian, spesies yang paling dominan pada bulan Maret dan Mei yaitu Stigeoclonium sp., sedangkan pada bulan Juli yaitu Rivularia sp.

Stigeoclonium sp. merupakan mikroalga heterotrichous dengan thallus berfilamen, biasanya ditemukan dalam air yang mengalir lambat dengan $\mathrm{pH}$ 6,14. Bagian basal sel Stigeoclonium menempel ke permukaan substrat seperti batu atau makrofita melalui filamen, namun dapat lepas dan ditemukan mengambang bebas di perairan (Singh et al., 2013; Branco \& Pereira, 2002). Rivularia sp., hidup berkoloni dan merupakan prokariot kosmopolit yang dapat ditemukan di hampir setiap habitat seperti laut dan air tawar, tanah dan batuan, gurun, mata air panas hingga danau. Spesies ini berperan penting dalam proses suksesi di perairan, dalam siklus nutrien, dan sebagai pupuk alami yang potensial untuk pertanian (Vaishampayan et al., 2001).

Secara umum, kualitas air Danau Tempe di setiap stasiun mengelompok berdasarkan waktu sampling dan pengukuran, pada bulan Mei dan Juli cenderung menyebar pada sumbu 
satu dan pada bulan Maret sebagian besar menyebar pada sumbu dua. Parameter yang berpengaruh cukup kuat pada bulan Juli adalah $\mathrm{pH}$ dan TN, pada bulan Mei adalah konduktivitas, TP, dan fosfat, sementara pada bulan Maret adalah DO dan ORP (Gambar 4).

Suhu dan $\mathrm{pH}$ air relatif tidak berfluktuasi secara berarti, namun kedua parameter ini merupakan faktor penting bagi mikroalga epifiton. Peningkatan $\mathrm{pH}$ merupakan efek dari aktivitas fotosintesis epifiton, sementara suhu air akan berpengaruh pada komposisi spesies dan laju pertumbuhan sel mikroalga (Lürling \& Oosterhout, 2013; Castenholz, 1969).

Oksigen terlarut dapat berasal dari fotosintesis dan dari udara yang masuk ke dalam air. Aktivitas fotosintesis yang dilakukan mikroalga meningkatkan konsentrasi oksigen terlarut dan $\mathrm{pH}$ di perairan (Nofdianto, 2010). Selain itu, menurut Albay dan Aykulu (2002) parameter fisika-kimia perairan seperti suhu air, pH tinggi, cahaya, dan kualitas air secara signifikan memengaruhi kolonisasi alga epifiton di perairan.

Nitrogen $(\mathrm{N})$ dan fosfor (P) adalah nutrien penting yang dalam jumlah berlebihan akan mencemari perairan. Nitrogen diperlukan untuk menyintesis protein dalam jaringan tumbuhan dan hewan. Fosfor terdapat dalam bentuk organik dan anorganik terlarut atau melekat pada partikel sedimen. Fosfat yang berbentuk anorganik lebih disukai untuk pertumbuhan tanaman, tetapi bentuk lain dapat digunakan ketika fosfat tidak tersedia (Minnesota Pollution Control Agency, 2008; Smith et al., 1999). Keberadaan fosfat di perairan berasal dari limpasan tanah pertanian (pupuk, kotoran.) dan limbah cair yang mengandung deterjen, serta zat aditif makanan dan minuman (Minnesota Pollution Control Agency, 2007).

Pembakaran makrofita pada musim kemarau seperti praktik pembakaran terkontrol secara tradisional (indigenous patch-burning) di Taman Nasional Kakadu, Australia, merupakan cara pengelolaan ekosistem yang ideal untuk danau paparan banjir (Bayliss et al., 2012; Pettit et al., 2011). Cara ini akan menciptakan area terbuka di danau tersebut yang biasanya akan ditumbuhi oleh komunitas makrofita terendam yang kompleks seperti Ceratophyllum demersum, Nepeta tenuifolia, dan Utricularia aurea selama periode banjir. Dengan demikian, jumlah dan luas area yang relatif terbuka dengan produktivitas alga yang tinggi akan meningkat, sehingga secara keseluruhan terjadi peningkatan produktivitas alga di danau, yang pada gilirannya akan meningkatkan produktivitas sekunder berupa ikan, karena mereka bermigrasi ke danau selama musim hujan tersebut (Jardine et al., 2012).

\section{Kesimpulan}

\begin{tabular}{crrr} 
Kelimpahan dan & \multicolumn{2}{c}{ keanekaragaman } \\
mikroalga epifiton di Danau Tempe
\end{tabular} dipengaruhi oleh kerapatan tumbuh makrofita. Vegetasi yang rapat akan membatasi penetrasi cahaya, sehingga perkembangan dan biomassa epifiton menjadi terhambat. Sebaliknya, makrofita dengan kerapatan rendah memiliki kelimpahan epifiton lebih tinggi. Dengan memperhatikan kerapatan makrofita, pengelolaan sumber daya perairan Danau Tempe berbasis dinamika populasi epifiton akan menjamin peningkatan produktivitas danau. Hasil penelitian ini perlu ditindaklanjuti dengan beberapa pengujian seperti pengaruh pasang surut, pembentukan rantai makanan sebagai cadangan makanan dan efek ekofisiologi lain dari vegetasi yang tumbuh sangat rapat serta kaitannya dengan komunitas ikan-ikan asli di Danau Tempe.

\section{Ucapan Terima Kasih}

Penelitian ini terlaksana atas dukungan Anggaran DIPA Tahun 2017 dalam kegiatan "Konsep Pengelolaan Perikanan Berbasis Daya Dukung Perairan". Ucapan terima kasih kami sampaikan kepada rekan-rekan peneliti Yustiawati, M. Suhaemi Syawal, Rosidah, Riky Kurniawan atas kerja sama yang baik selama survei, seluruh tim analis di Laboratorium Pusat Penelitian Limnologi LIPI, dan Jojok Sudarso yang telah membantu dalam analisis PCA.

\section{Referensi}

Aisyah S, Nomosatryo S. 2016. Spatial and Temporal Distribution of Nutrient in Lake Tempe, South Sulawesi. Oseanologi dan Limnologi di Indonesia 1: 31-45

Albay M, Aykulu G. 2002. Invertebrate Grazer - Epiphytic Algae Interactions on Submer- 
ged Macrophytes in a Mesotrophic Turkish Lake. E.U. Journal of Fisheries \& Aquatic Sciences 19: 247-258

APHA (American Public Health Association). 2015. Standard Methods for the Examination of Water and Wastewater. 19th Edition. Washington

Aquaculture SA. 2003. Water quality in freshwater aquaculture ponds. Aquaculture SA of Primary Industries and Resources South Australia (PIRSA), April 2003. Fact Sheet No. 60/01. www.pir.sa.gov.au/fact sheets

Bayliss P, van Dam RA, Bartolo RE. 2012. Quantitative Ecological Risk Assessment of the Magela Creek Floodplain in Kakadu National Park , Australia : Comparing Point Source Risks from the Ranger Uranium Mine to Diffuse Landscape-Scale Risks. Human and Ecological Risk Assessment 18: $115-151$

DOI: $10.1080 / 10807039.2012 .632290$

Benckiser R. 2019. Rate of photosynthesis : limiting factors. http://www.rsc.org/learnchemistry/content/filerepository/CMP/00/00 1/068/Rate\%20of\%20photosynthesis\%20lim iting\%20factors.pdf, 1-2

Blanco S, Romo S, Fernández-Aláez, Bécares E. 2008. Response of epiphytic algae to nutrient loading and fish density in a shallow lake: A mesocosm experiment. Hydrobiologia 600: 65-76. DOI: 10.1007/s10750-007-9176-0

Branco LHZ, Pereira JL. 2002. Evaluation of seasonal dynamics and bioindication potential of macroalgal communities in a polluted tropical stream. Archiv fur Hydrobiologie 155: 147-161

Caruso T, Pigino G, Bernini F, Bargagli R, Migliorini M. 2007. The Berger - Parker index as an effective tool for monitoring the biodiversity of disturbed soils : a case study on Mediterranean oribatid ( Acari : Oribatida ) assemblages. Biodiversity Conservation 16: 3277-3285. DOI: $10.1007 / \mathrm{s} 10531-006-$ 9137-3

Castenholz RW. 1969. Thermophilic BlueGreen Algae and the Thermal Environment. Bacteriological Reviews 33: 476-504

Chung M-H, Lee K-S. 2008. Species Composition of the Epiphytic Diatoms on the Leaf Tissues of Three Zostera Species Distributed on the Southern Coast of Korea. Algae 23: 75-81
Dere Ş, Karacaoglu D, Dalkiran N. 2002. A Study on the Epiphytic Algae of the Nilüfer Stream ( Bursa ). Turk. J. Bot. 26: 219-233

EPA (Environmental Protection Agency). 2001. PARAMETERS OF WATER QUALITY Interpretation and Standards

Jardine TD, Pusey BJ, Hamilton SK, Pettit NE, Davies PM, Douglas MM, Sinnamon V, Halliday IA, Bunn SE. 2012. Fish mediate high food web connectivity in the lower reaches of a tropical floodplain river. Oecologia 168: 829-838. DOI: 10.1007/s00442-011-2148-0

Jaschinski S, Brepohl DC, Sommer U. 2011. The trophic importance of epiphytic algae in a freshwater macrophyte system ( Potamogeton perfoliatus L .): Stable isotope and fatty acid analyses. Aquatic Sciences 73 : 91-101. DOI: 10.1007/s00027-010-0163-6

Lürling M, Oosterhout F. 2013. Case study on the efficacy of a lanthanum-enriched clay ( Phoslock ${ }^{\circledR}$ ) in controlling eutrophication in Lake Het Groene Eiland ( The Netherlands ). Hydrobiologia 710: 253-263. DOI: 10.1007/s10750-012-1141-x

Messyasz B, Kuczynska-Kippen N, Nagengast B. 2009. The epiphytic communities of various ecological types of aquatic vegetation of five pastoral ponds. Biologia 64: 88-96. DOI: 10.2478/s11756-009-0006$\mathrm{x}$

Messyasz B, Rybak A. 2009. The distribution of green algae species from the Ulva genera ( syn . Enteromorpha; Chlorophyta) in Polish inland waters. Oceanological and Hydrobiological Studies 38: 1-18. DOI: 10.2478/v10009-009-0001-0

Minnesota Pollution Control Agency. 2007. Phosphorus: Sources, Forms, Impact on Water Quality

Minnesota Pollution Control Agency. 2008. Nutrients: Phosphorus, Nitrogen Sources, Impact on Water Quality.

Mizuno T. 1979. Illustrations of the Freshwater Plankton of Japan. Huikusha Publishing Co. Ltd. Osaka, Japan

Nasir M, Nur M. 2017. Komposisi Tanaman Akuatik di Danau Tempe Kabupaten Wajo dan Pemanfaatannya sebagai Media Pembelajaran Ekologi Tumbuhan. Prosiding Seminar Nasional Biologi dan Pembelajarannya, 509-514

National Optical Astronomy Observatory (NOAO). (n.d.). Recommended Light Levels 
(Illuminance) for Outdoor and Indoor Venues

Nofdianto. 2010. Net Production Modeling of Phytobenthos: Integration on A Section of Garonne River According to the Season. LIMNOTEK Perairan Darat Tropis di Indonesia 17: 210-217

Nofdianto. 2013. AKTIVITAS "BUNGKA TODO" DAN LAJU PRODUKTIVITAS PRIMER DANAU TEMPE SULAWESI SELATAN. Prosiding Pertemuan Ilmiah Tahunan MLI I, Cibinong 3 Desember 2013. Perkembangan Limnologi dalam Mendukung Pembangunan Berkelanjutan di Indonesia: Tantangan dan Harapan, 229235

Odum EP. 1971. Fundamentals of Ecology. Third Edition, WB Saunders Co. Philadelphia

Öterler B. 2017. Community Structure , Temporal and Spatial Changes of Epiphytic Algae on Three Different Submerged Macrophytes in a Shallow Lake. Pol. J. Environ. Stud. 26: 2147-2158. DOI: 10.15244/pjoes/70232

Pelicice FM, Thomaz SM, Agostinho AA. 2008. Simple relationships to predict attributes of fish assemblages in patches of submerged macrophytes. Neotropical Ichthyology 6: 543-550

Pentecost A, Whitton BA. 2012. The Ecology of Cyanobacteria. Their Diversity in Time and Space. Ecology of Cyanobacteria II: Their Diversity in Space and Time, 291-316. DOI: 10.1007/978-94-007-3855-3

Peraturan Pemerintah Republik Indonesia No. 82 Tahun 2001 tentang Pengelolaan Kualitas Air dan Pengendalian Pencemaran Air

Pettit NE, Bayliss P, Davies PM, Hamilton SK, Warfe DM, Bunn SE, Douglas MM. 2011. Seasonal contrasts in carbon resources and ecological processes on a tropical floodplain. Freshwater Biology 56: $1047-$ 1064. DOI: 10.1111/j.1365-2427.2010. 02544.x

Pettit NE, Ward DP, Adame MF, Valdez D, Bunn SE. 2016. Influence of aquatic plant architecture on epiphyte biomass on a tropical river floodplain. Aquatic Botany 129: 35-43. DOI: doi.org/10.1016/j.aquabot.2015.12.001

Prescott GW. 1970. How to know the Freshwater Algae. WMC Brown Company Publisher. Iowa
Samuel, Makmur S, Pong Masak PR, Farid A, Adiansyah V, Selamet S, Burnawi, Hifni T. 2010. Kajian Stok Sumber Daya Perikanan di Perairan Danau Tempe, Sulawesi Selatan

Santos TR, Ferragut C, Bicudo CEM. 2018. Relationship among carnivorous macrophyte Utricularia foliosa L . and species composition and life forms of periphytic algae community. Acta Limnologica Brasiliensia 30. DOI: 10.1590/S2179975X5217

Singh UB, Ahluwalia AS, Sharma C, Jindal R, Thakur RK. 2013. Planktonic indicators : A promising tool for monitoring water quality (early-warning signals). Ecology, Environment and Conservation - 19: 793-800

Smith VH, Tilman GD, Nekola JC. 1999. Eutrophication: impacts of excess nutrient inputs on freshwater, marine, and terrestrial ecosystems. Environmental Pollution 100: 179-196

Stenger-Kovács C, Buczkó K, Hajnal E, Padisák J. 2007. Epiphytic, littoral diatoms as bioindicators of shallow lake trophic status: Trophic Diatom Index for Lakes (TDIL) developed in Hungary. Hydrobiologia 589: 141-154. DOI: 10.1007/s10750-007-0729-z

Sultana M, Asaeda T, Azim ME, Fujino T. 2010. Morphological responses of a submerged macrophyte to epiphyton. Aquatic Ecology 44: 73-81. DOI: 10.1007/s10452-009-9291-2

Thomaz SM, Cunha ER. 2010. The role of macrophytes in habitat structuring in aquatic ecosystems: Methods of measurement, causes and consequences on animal assemblages' composition and biodiversity. Acta Limnologica Brasiliensia 22: 218-236. DOI: 10.4322 /actalb.02202011

Twilley RR, Kemp WM, Staver KW, Stevenson JC, Boynton WR. 1985. Nutrient enrichment of estuarine submersed vascular plant communities. 1. Algal growth and effects on production of plants and associated communities. MARINE ECOLOGY PROGRESS SERIES 23: 179-191

Vaishampayan A, Sinha RP, Hader DP, Dey T, Gupta AK, Bhan U, Rao AL. 2001. Cyanobacterial Biofertilizers in Rice Agriculture. The Botanical Review 67: 453516

Wetzel RG. 1983. Limnology. Second Edition. Saunders College Publishing. Philadelphia 
Woods C. 2013. Factors Influencing the Distribution and Structure of Tropical
Vascular Epiphyte Communities at Multiple Scales. Clemson University 